\title{
51. FORMATION AND DESTRUCTION OF THE ERATOSTHENES SEAMOUNT, EASTERN MEDITERRANEAN SEA, AND IMPLICATIONS FOR COLLISIONAL PROCESSES ${ }^{1}$
}

\author{
Alastair H.F. Robertson ${ }^{2}$
}

\begin{abstract}
The first of two tectonic-oriented objectives during Leg 160 in the Eastern Mediterranean Sea (April-May, 1995) was concerned with study of processes of genesis and incipient collision of the Eratosthenes Seamount, a substantial crustal feature, with the active margin of the Eurasian plate to the north, represented by southern Cyprus. The upper part of the Eratosthenes Seamount (upper several hundred meters) was found to include both shallow- and deep-water carbonates dating back to preAptian time (Early Cretaceous). Shallow-water platform carbonate deposition, similar to that of the onshore Levant continental margin to the east (part of the North African plate), was followed by submergence to bathyal depths in the Late Cretaceous to middle Eocene, punctuated by depositional and tectonic hiatuses. Tectonic uplift $(\sim 1 \mathrm{~km})$ was followed by shallow-water carbonate deposition in the Miocene. The platform was subaerially exposed during the Messinian desiccation crisis. During the early Pliocene, the platform subsided to bathyal depths associated with localized accumulation of limestone debris flows. Subsidence accelerated in the late Pliocene-early Pleistocene.

Interpretation of site-survey seismic data suggests that the base of the northern slope of the Eratosthenes Seamount is in the processes of detachment to form an allochthonous thrust slice, with implications for the formation of on-land melange terrains. Comparisons can be made with the collapse, high-angle faulting, and partial subduction of the mainly igneous Daisha Seamount in the Japan trench, and counterparts in the Mariana and Izu-Bonin fore-arcs, and elsewhere. The break-up of the Eratosthenes Seamount was achieved by loading-related flexural subsidence, accompanied by high-angle normal faulting, which may have exploited pre-existing structural weaknesses. Subsidence of the Eratosthenes Seamount was synchronous with rapid surface uplift of the over-riding plate, represented by the late Pliocene-mid-Pleistocene uplift of the Troodos ophiolite and its sedimentary cover. The flexural and isostatic effects of sediment loading and flooding of the Mediterranean Sea after the Messinian also influenced subsidence of the Eratosthenes Seamount, to some extent. The ultimate fate of the Eratosthenes Seamount is likely to be preservation as allochthonous slices, mainly limestone, within a subduction-accretion complex, forming part of a collisional suture zone. Accretionary units similar to the Eratosthenes Seamount are indeed found within the Tethyan orogenic belt to the north, in areas including Turkey and Greece.
\end{abstract}

\section{INTRODUCTION}

The aim here is to synthesize the main tectonic results of drilling of the Eratosthenes Seamount in the Eastern Mediterranean Sea during Leg 160 (April-May, 1995). Results obtained during shore-based research will be highlighted, following publication of a preliminary synthesis based on shipboard results (Emeis, Robertson, Richter, et al., 1996; Robertson et al., 1996; Mart et al., 1997; Robertson et al., 1997). The results can be related to the tectonic evolution of the Eratosthenes Seamount in its regional Eastern Mediterranean context. The drilling also has implications for the mechanism of subsidence and break-up of continental fragments at subduction zones, and the preservation of crustal fragments in subduction/ accretion complexes within orogenic belts.

One of two tectonic objectives of drilling during Leg 160 was concerned with the process of break-up of a carbonate platform, the Eratosthenes Seamount, at a subducting plate boundary, represented by the Cyprus active margin (Sites 965-968 inclusive; Fig 1). The Eastern Mediterranean Sea is an ideal location for study of crustal processes related to the collision of continental plates. The northern, passive margin of the African plate (Gondwana) rifted in the early Mesozoic, giving rise to an irregular pattern of embayments and promontories (e.g., Dercourt et al., 1993). Continental fragments were rifted from Gondwana and drifted northward into the Tethys

${ }^{1}$ Robertson, A.H.F., Emeis, K.-C., Richter, C., and Camerlenghi, A. (Eds.), 1998. Proc. ODP, Sci. Results, 160: College Station, TX (Ocean Drilling Program).

${ }^{2}$ Department of Geology and Geophysics, University of Edinburgh, West Mains Road, Edinburgh EH9 3JW, U.K. Alastair.Robertson@glg.ac.ed.uk
Ocean (i.e., Neotethys). The opposing, northern margin of Neotethys (the southern margin of Eurasia) was initially located well to the north, extending from northern Greece through the Pontides of northern Turkey into the Caucasus. Africa and Eurasia converged in the late Mesozoic-early Tertiary, accommodated by subduction. As northward subduction progressed, a number of continental fragments (previously rifted from Gondwana) were accreted to the active southern margin of Eurasia. Examples of such fragments include the Kerşehir, Menderes-Bey Dağları and Bitlis-Pütürge units in Turkey and the Parnassus unit in Greece (Şengör and Yilmaz, 1981; Robertson and Shipboard Scientific Party, 1996). As accretion progressed, the overall subduction front migrated southward with time. By the Miocene, the seamount was located in the vicinity of the present convergent plate boundary, which extends across the Eastern Mediterranean Sea south of Crete, and then south of Cyprus to connect with the Tethys suture zone farther east. At the present time, the Eastern Mediterranean Sea can be considered a remnant of the southerly Mesozoic Neotethys in its final stages of closure, associated with diachronous collision of the African and Eurasian plates. Alternative tectonic interpretations of the plate tectonic evolution of the easternmost Mediterranean region as a whole are discussed in Robertson et al. (1996).

In this paper the main results of drilling of the Eratosthenes Seamount are summarized and discussed. The reader is referred to the individual chapters of this volume for the presentation of original results and interpretation. In addition, the history of geophysical exploration of the Eratosthenes Seamount and surrounding areas are summarized in a companion synthesis paper (Mart and Robertson, Chap. 52, this volume). The wider tectonic evolution of the easternmost Mediterranean region is also discussed in more detail in another synthesis chapter (Robertson, Chap. 54, this volume). 


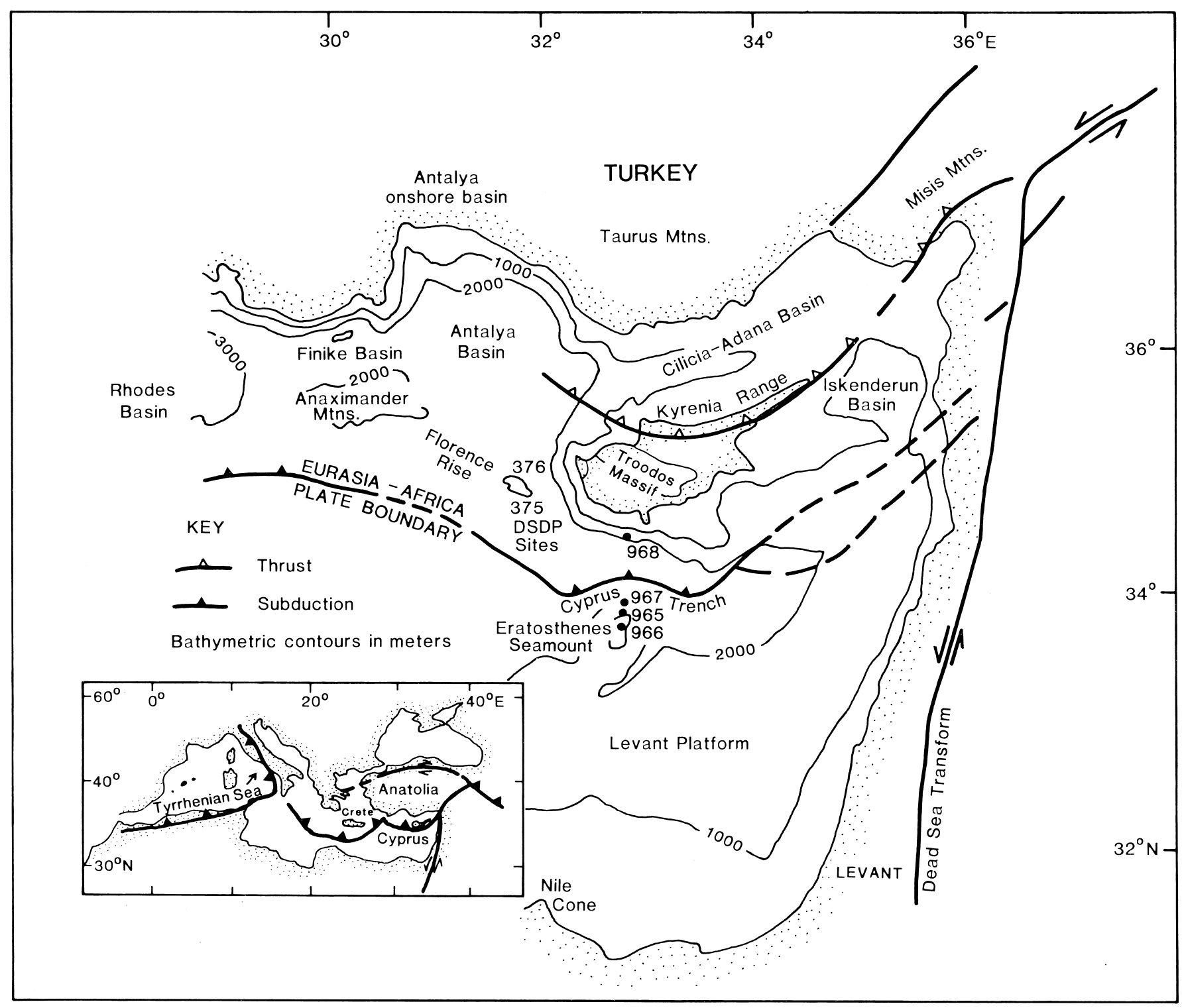

Figure 1. Outline map of the easternmost Mediterranean region showing the main tectonic features and the locations of the sites drilled during Leg 160, specifically the Eratosthenes Seamount.

\section{REGIONAL SETTING OF THE ERATOSTHENES SEAMOUNT}

The Eratosthenes Seamount is located in the easternmost Mediterranean Sea south of Cyprus and north of the Nile delta, with the passive margin of the Levant to the east. The term seamount has given rise to some confusion in the past, because to many it implies an origin as mainly extrusive igneous rocks, whereas drilling during Leg 160 has shown that at least the upper part (i.e., all that is known) is predominantly limestone, without igneous rocks. The nature of the underlying basement remains controversial, but the absence of a well-defined gravity anomaly, as opposed to a marked magnetic anomaly, has suggested to many that Eratosthenes is a rifted continental fragment, coupled with rift-related intrusions or extrusions of basic or ultrabasic igneous rocks (Ben-Avraham et al., 1976; Woodside and Bowin, 1970; Woodside, 1977; see also Kempler, Chap. 53, this volume, and Mart and Robertson, Chap. 52, this volume, for literature review).
The easternmost Mediterranean is a part of the wider Eastern Mediterranean Sea that formed by rifting of the north margin of Gondwana in the Triassic (Garfunkel and Derin, 1984). The Eratosthenes Seamount is envisaged as a carbonate platform constructed on a rifted continental fragment (relatively thin continental crust), as noted above. Oceanic crust was formed in the easternmost Mediterranean by the Late Triassic and is represented by "accreted" fragments in southwest Cyprus (Mamonia Complex), southwest Turkey (Antalya Complex), and northern Syria (Baer-Bassit) (Robertson et al., 1991a; Mart and Robertson, Chap. 52, and Robertson, Chap. 54, both this volume). The easternmost Mediterranean represents the most southerly of several Mesozoic Neotethyan oceanic basins, separated by continental slivers that were rifted from Gondwana, including the Tauride carbonate platforms of southern Turkey and the Pelagonian Zone in Greece. In the Cretaceous, the relative motion of the African and Eurasian plates became convergent, coupled with opening of the south Atlantic (Livermore and Smith, 1984; Savostin et al., 1986). In response to this regional plate convergence, subduction was 
initiated within the southerly Eastern Mediterranean ocean basin (and more northerly basins also), specifically leading to genesis of the Troodos ophiolite by spreading above a subduction zone (see Robertson and Xenophontos, 1993, for summary of literature). The subduction zone probably dipped northward and was located south of Cyprus. During the Late Cretaceous-early Eocene, much of Cyprus underwent counterclockwise rotation as a discrete microplate (Clube and Robertson, 1986; Morris et al., 1990). Northward subduction of remaining oceanic crust in the easternmost Mediterranean to the south of Cyprus began in early Miocene, or possibly late Oligocene time, and the North African plate, including the Eratosthenes "Seamount," then began its final northward drift toward Cyprus (e.g., Dewey and Şengör, 1979). During this time, southern Cyprus was located on the leading edge of what had by then become the Eurasian plate.

The Eratosthenes Seamount forms a large sub-rectangular, elevated feature in the Mediterranean Sea south of Cyprus. Regional geophysical data indicate the presence of an important magnetic anomaly that extends beyond the topographic expression of the Eratosthenes Seamount. Previous work has already suggested that the seamount is in the processes of collision with the Cyprus active margin to the north (Robertson, 1990; Woodside, 1991; Kempler, 1993; Limonov et al., 1994; Mart and Robertson, Chap. 52, this volume; Robertson et al., 1995b, 1995c). There is also some evidence that the southern margin of the Eratosthenes Seamount is collapsing beneath the Levantine Basin to the south (Limonov et al., 1994). Previously, limestone was dredged from the Eratosthenes Seamount (Krasheninnikov et al., 1994), and Leg 160 confirmed that the upper levels of the structure are, indeed, composed of limestone.

A collision-related tectonic hypothesis for the emplacement of the Eratosthenes Seamount could only be tested by drilling. The test had to involve only relatively shallow penetration (i.e., mainly a few hundred meters), as time and safety considerations precluded deeper penetration. It was never envisaged that the drilling could answer questions about the nature of the basement or the early history, although units as old as Early Cretaceous were reached during Leg 160 drilling.

Key questions that were expected to be answered by drilling of relatively shallow holes were the lithology of the upper part of the Eratosthenes Seamount, and the timing and processes of subsidence that might be related to collision with the Cyprus active margin to the north. To achieve these objectives a transect of four holes was drilled, from north to south: one on the northern crestal area of the Eratosthenes Seamount (Site 966), one on the upper northern flanks (Site 965), one at the base of the northern slope (Site 967), and one at the base of the opposing slope of the Cyprus active margin (Site 968; Fig. 1).

Suture zones in Greece, Turkey, and other Tethyan areas include numerous deformed carbonate platforms (see Robertson, 1994, for literature review). These platforms mainly overlie rifted continental crust, although some may overlie oceanic crust (i.e., volcanic seamounts). Examples include the Mesozoic Tauride carbonate platforms of southern Turkey and counterparts in Greece and in the Alps. An important question is how these platforms came to be incorporated into the Tethyan orogenic collage. Similar carbonate bodies are present in accretionary units in many other areas, notably in the circum-Pacific, including the Franciscan complex in the western U.S.A. and the Shumanto Belt in southwest Japan. Drilling of the Eratosthenes Seamount, combined with seismic data, has revealed a mechanism whereby kilometer-sized slices of sedimentary rocks can be detached and accreted in an incipient collisional setting.

\section{SUMMARY OF DRILLING RESULTS}

Details of the recovery at each of the sites drilled are given in the Leg 160 Initial Reports volume (Emeis, Robertson, Richter, et al.,
1996). The main results are summarized here, utilizing five time slices, with emphasis on postcruise results (Fig. 2): Early CretaceousPaleogene, Miocene, Messinian (latest Miocene), early Pliocene, and Pliocene-Pleistocene.

\section{Early Cretaceous-Paleogene}

The history of the Eratosthenes Seamount, as recorded by drilling at Site 967, began with the accumulation of shallow-water platform carbonates including coral, calcareous red algae, and occasional large foraminifers (Emeis, Robertson, Richter, et al., 1996; Robertson, Chap. 32, this volume). The Formation MicroScanner (FMS) and conventional $\log$ data reveal brecciated or nodular units within an overall horizontally bedded unit (Major et al., Chap. 38, this volume). Deposition in pre-Aptian time comprised shallow-water carbonates, including coral and calcareous algae. Micropaleontological evidence suggests that this carbonate deposition ended in pre-Aptian time (Premoli-Silva et al., Chap. 30, this volume). The shallow-water limestones are lithologically similar to those of the Levant (Mart et al., 1997; Mart and Robertson, Chap. 52, this volume). However, the submergence of a comparable shallow-water carbonate platform to a bathyal setting appears to have taken place slightly later in both southern Turkey (in the Cenomanian) and the Levant (in the Turonian; Robertson, Chap. 32, this volume). On the Eratosthenes Seamount this transition is marked by some sediment reworking and was probably tectonically controlled.

The neritic sediments are overlain by Late Cretaceous pelagic carbonates that are locally organic rich and commonly contain chert of replacement origin (Robertson, Chap. 32, this volume). Coniacian to Maastrichtian ages were determined for these pelagic carbonates using calcareous nannofossils and planktonic foraminifers (PremoliSilva et al., Chap. 30, this volume). There is a probable hiatus spanning the Albian and part of the Cenomanian. Maastrichtian pelagic carbonates are overlain by lithologically similar chalks of early Paleocene and early Oligocene age, with extensive reworking of older taxa. However, the presence of reworked taxa of early and middle Paleocene and parts of the early and late Eocene suggest that deposition was originally more continuous with less marked hiatuses than at present. Stable isotopic data are difficult to interpret, as the recovery was fragmentary, but correlation with well-dated land successions in central Italy at least allows the base of the Coniacian to be recognized, based on a significant negative carbon excursion (PremoliSilva et al., Chap. 30, this volume). Within the Turonian, a hiatus spanning the middle to late $H$. helvetica Zone and the $M$. sigali Zone is probably also present (Premoli-Silva et al., Chap. 30, this volume).

The presence of reworked taxa suggest that deposition was originally relatively complete during Late Cretaceous and early Tertiary time, followed by reworking, rather suggesting major hiatuses with no accumulation at all for very lengthy time periods (Premoli-Silva et al., Chap. 30, this volume). The log data do not reveal any significant change over the Cretaceous-Tertiary boundary (Emeis, Robertson, Richter et al.; M.J. Jurado-Rodríguez, unpubl. data). The log data support the inference that pelagic sedimentation continued at Site 967 from the Late Cretaceous, through the Oligocene to the Miocene, albeit with discontinuities in deposition. This contrasts somewhat with an initial shipboard view that Site 967 was located on an upfaulted block subject to subaerial erosion, at least during late Miocene-early Pliocene time (Robertson and Shipboard Scientific Party, 1996, fig. 4). Overall, the conventional logs suggest increasing cementation downward. More or less resistive layers are correlated with intercalations of calcarenite (i.e., grainstone) and calcilutite (i.e., wackestone; Major et al., Chap. 38, this volume). Also, FMS images indicate the presence of chert, which was recovered only as occasional fragments.

Lithologically similar pelagic carbonates, of middle Eocene age, were recovered farther south at Site 966, where a number of intervals are enriched in uranium, thorium, and potassium (Major et al., Chap. 


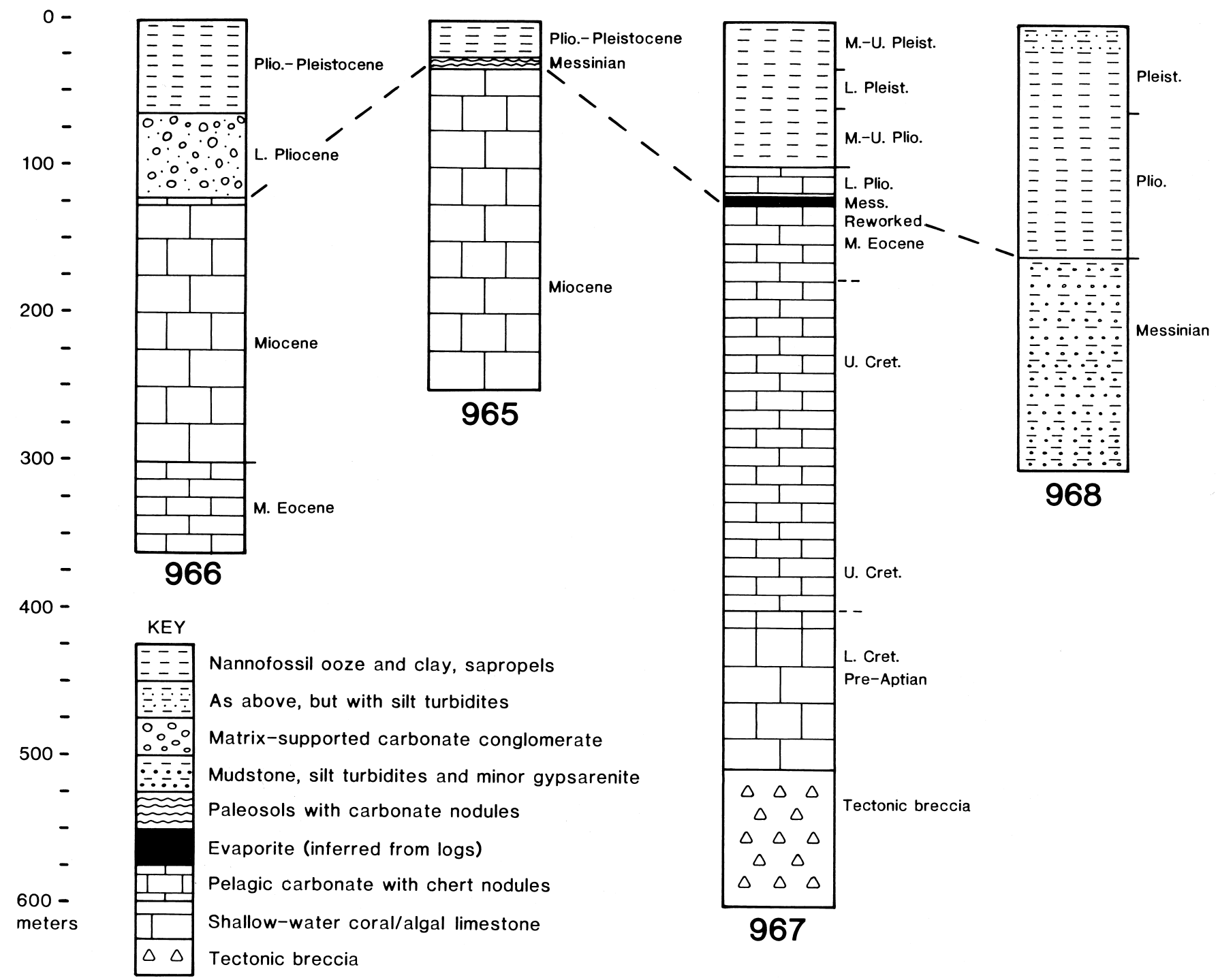

Figure 2. Summary of the successions recovered from the Eratosthenes Seamount during Leg 160 (see text for explanation).

38, this volume). Also, chert nodules appear to be abundant in the lower part of the succession based on FMS images, although they were rarely cored. The top of the Eocene succession is marked by high uranium contents that might suggest that the overlying planar unconformity was a hardground or an interval of greatly reduced net sediment accumulation (Major et al., Chap. 38, this volume).

Minor tectonic instability is indicated by localized syndepositional neptunian fissuring, which could record subtle extension or tilting. There is no evidence of major tectonic disruption (e.g., collapse or foredeep development) that could correspond to the tectonic emplacement of Late Cretaceous ophiolites, as known from more northerly parts of the Neotethys ocean (e.g., Troodos ophiolite, Cyprus). The probable explanation for the lack tectonic disruption is that in the Late Cretaceous-early Tertiary the Eratosthenes Seamount still lay well to the south of the plate boundary, whereas the ophiolites were formed farther north. The Eratosthenes Seamount is interpreted as then being located seaward of a zone of high plankton productivity that affected the adjacent Levant passive margin (Almogi-Labin et al., 1993). In general, the nature of the Cretaceous-Paleogene Eratosthenes carbonates is consistent with accumulation on an initially shallow, then submerged, carbonate platform that was isolated within a southerly branch of the Neotethyan ocean (Robertson, Chap. 32, this volume).

\section{Miocene}

After the middle Eocene at Site 966 and the Oligocene at Site 967, there was a hiatus that culminated in the Eratosthenes Seamount being tectonically uplifted by $\sim 1 \mathrm{~km}$. At Site 966 , an unconformity between the two units is marked by different dip directions, with dips to the northwest in the middle Eocene, but to the northeast in the Miocene sediments (Flecker et al., Chap. 40, this volume). The uplift allowed deposition of shallow-water carbonates to be initiated. The exact timing of uplift and whether uplift was gradual or abrupt remain uncertain, as the base of the shallow-water carbonates is still poorly dated. However, the nature of the underlying succession and the log data suggest that no deep erosion is likely to have taken place. The underlying Oligocene and Eocene pelagic limestones show no petrographic evidence of subaerial weathering or karstification. Also, the uplift was not associated with any marked deformation of the under- 
lying succession (e.g., folding), based on interpretation of seismic data (Limonov et al., 1994). It is, thus, likely that uplift was restricted to near sea-level. Progressive subsidence then appears to have taken place providing the accommodation space needed for Miocene shallow-water carbonate accumulation.

Neritic carbonates were deposited at the two most southerly sites on the Seamount (Sites 965 and 966). The limestones recovered during drilling are at present dated only as Miocene at Site 966, based on a benthic foraminiferal assemblage, that is provisionally referred to the family Orbitoididae (I. Premoli-Silva, pers. comm., 1995). However, at present it is unclear if the limestones span much, or all, of the Miocene, or are limited to specific intervals. For example, up-building could have taken place mainly during relative sea-level highs when growth was stimulated (e.g., Burdigalian). Preliminary Sr isotopic age data suggest a late Miocene age for part of the succession at Site 965, which was not dated paleontologically (E. Frankel, pers. comm., 1996). Grainstones appear to become more common near the top of the succession, whereas mudstone is more common lower down at Site 965.

The Eratosthenes limestones show similar biodiversity to the Burdigalian (early Miocene) reefs of southeastern and western Cyprus, but differ from the Tortonian (late Miocene) nearly monospecific coralline reefs elsewhere in Cyprus (Follows et al., 1996). In general, similar Miocene shallow-water and reef-related carbonates are known in other areas of the eastern Mediterranean including Israel, southern Turkey, and Cyprus (e.g., Flecker et al., 1995; Hayward et al., 1996; Follows and Robertson, 1990; Follows et al., 1996), and occurrences are summarized in Robertson (Chap. 33, this volume). The Eratosthenes Miocene reefs can be interpreted either as patch reefs (likely), or an atoll-like structure, as in the modern Indo-Pacific region.

The limestones at both Sites 965 and 966 are mainly composed of mat-like coralline algae, Porites sp. coral, large benthic foraminifers, pelecypods, echinoderm plates, and localized sponge spicules. Colonial coral is reworked at both sites and in situ boundstone was not drilled. The material at Site 965 appears to be more reef proximal than that at Site 966. Intercalations of micrite containing planktonic foraminifers point to surrounding open-marine conditions. The finer grained, reworked material with numerous micritic intercalations at Site 966 is interpreted to have accumulated in a lagoonal setting (Emeis, Robertson, Richter, et al., 1996; Robertson, Chap. 33, this volume).

Additional clues to the environment of deposition come from FMS and conventional log data (Emeis, Robertson, Richter, et al.,1996; M.J. Jurado-Rodríguez et al., pers. comm., 1996). Numerous alternations of less resistant intervals determined from FMS and conventional log data are interpreted as being a result of the presence of more argillaceous layers that were rarely cored. The lower part of the Miocene succession is relatively massive, while layering becomes more clearly defined higher in the succession. Occasional discontinuities could be interpreted as erosional disconformities. Strong variability in inferred porosity could relate to observed diagenetic solution within the cores (Major et al., Chap. 38, this volume). In addition, apparently cross-laminated units were observed on the FMS images. However, despite the limited recovery no direct evidence of cross-lamination was seen in the cores, suggesting that the recognition of cross lamination using FMS data may need to be re-assessed.

Based on petrographic analysis, the shallow-water carbonates at both Sites 965 and 966 experienced a similar diagenetic history. Early void-filling cement included fibrous, accicular calcite, of probable marine origin (i.e., high-Mg calcite, or aragonite). Aragonite is commonly preserved, while high-magnesian calcite is replaced by lowmagnesian calcite, based on whole-rock X-ray diffraction and electron microprobe data. The presence of extensive solution porosity is attributed to flushing by meteoric waters during the Messinian salinity crisis when the Eratosthenes Seamount was exposed above the level of evaporite precipitation. Common dolomite could have formed in a mixing zone related to marine transgression in the early Pliocene, as inferred for the origin of similar dolomite in Cyprus (Follows, 1992). The Miocene shallow-water limestones also include minor opal and microcrystalline chert of probable biogenic origin (Robertson, Chap. 33, this volume).

At the northernmost site (Site 967) the Miocene is absent and Late Cretaceous-middle Eocene pelagic carbonates are directly overlain by fine-grained, deep-water sediments of early Pliocene age. Reworked microfossils of middle Eocene, Oligocene, and Mioceneearly Pliocene age are present within pelagic carbonates at the base of the lower Pliocene succession. The history of this site during the mid-Tertiary is, thus, debatable. One possibility is that Miocene shallow-water carbonates were deposited in a similar manner to those at Sites 965 and 966, but were later eroded. Indeed, Mart (1997) and Y. Mart (pers. comm., 1997) envisages that shallow-water Miocene carbonates accumulated at Site 967, similar to those at Sites 965 and 966 , but were later eroded following uplift related to initial collision of the Eratosthenes Seamount with the Cyprus active margin. This is unlikely, as there is a record of reworked Miocene (and older) planktonic foraminifers in Hole 967E (Emeis, Robertson, Richter, et al., 1996), indicating that at least some pelagic deposition continued during the Miocene at this site, whereas reworked shallow-water carbonate was not observed. Also, there is no evidence of tilting, angular discordance, or compressional deformation at Site 967 that could correspond to a regional collisional event in the late Miocene.

Another possibility is that Miocene shallow-water carbonates were never deposited at Site 967 , but that pelagic deposition took place instead, followed by gravity or current reworking. One specific possibility is that Site 967 was located on a carbonate slope subject to sediment redeposition, where only reduced pelagic deposition later took place during Eocene to late Miocene time. If this was the case, then the Cretaceous-Paleogene Eratosthenes carbonate platform was originally considerably larger than the Miocene carbonate platform. The older platform was possibly block-faulted before the Miocene, with only the southerly part becoming sufficiently shallow to allow colonization by coral, whereas the more deeply submerged northerly part continued to accumulate pelagic carbonate in a slope or basinal setting.

\section{Messinian}

The Mediterranean underwent its well-documented salinity crisis in the latest Miocene, as recorded during Legs 13 and 42 of the Deep Sea Drilling Project (Hsü et al., 1973; Hsü, Montadert, et al., 1978). Layers of evaporite, up to several kilometers thick, are inferred to exist beneath the deep Mediterranean basin, based mainly on recognition of a clear "M" reflector on seismic profiles (Ryan et al., 1971; Ross and Uchupi, 1977; Woodside, 1977). The "M" reflector pinches out up-slope on the south and southwest flanks of the Eratosthenes platform (Limonov et al., 1994). The top of the platform was above the level of the surrounding Mediterranean deep basin during the Messinian. A prominent reflector, thought to be an erosion surface, was noted at the base of the inferred Pliocene sequence, based on site survey studies (Limonov et al., 1994).

Drilling during Leg 160 confirmed that no thick evaporites are present on the Eratosthenes Seamount (Site 966), or on its northern margin (Sites 965 and 967). The Messinian is thin, or absent, on the Eratosthenes plateau area, as confirmed by drilling at Site 966 that revealed early Pliocene sediments resting unconformably on diagenetically altered Miocene shallow-water limestone. However, at Site 965 , several meters of reddish clays were recovered at the boundary between overlying sediments; these contain early Pliocene nannofossils and clasts of lithologies similar to the underlying Miocene shallow-water limestones. These clays contain many ostracode carapaces, together with dolomite, aragonite, and swelling clays. Isotopic 
analysis of one carbonate nodule recovered from Site 966 confirmed that it formed in a freshwater setting (Böttcher et al., Chap. 35, this volume), and thus the sediment is inferred to represent paleosol and caliche.

The $\log$ evidence (i.e., density and sonic velocity) suggests a marked change in physical properties at the top of the inferred paleosol (23-24 mbsf), that together with the presence of reworked nannofossils in this interval, might indicate reworking of the upper part of the paleosol during renewed marine transgression (Major et al., Chap. 38, this volume).

Also, at Site 967, near the base of an interval of muddy sediments that contains only reworked microfossils, an interval several meters thick (not recovered) was identified on geophysical borehole log records as evaporite. Corroboration of its existence comes from inorganic geochemical evidence of greatly increased levels of soluble sulfate at this level, and from the interpretation of geochemical logs (Emeis, Robertson, Richter, et al., 1996).

The log data indicate the presence of gypsum (at 115 to 125 mbsf), characterized by a distinctive FMS image, low radioactivity, high resistivity, characteristic density, sonic and neutron values, respectively (Emeis, Robertson, Richter, et al., 1996; M.J. JuradoRodríguez, pers. comm., 1996). An upper and a lower horizon of evaporites appear to be separated by an argillaceous layer. The FMS image suggests that the upper part of the evaporite is tilted $\left(10^{\circ}-20^{\circ}\right)$. The log data might reflect initial evaporite deposition, followed by argillaceous disposition, then by faulting, slumping, or reworking.

Postcruise studies have revealed the presence of an intact Messinian to Pliocene boundary succession at Site 967 . An almost continuous upper Messinian succession appears to be present, as confirmed by the presence of Cyprideis pannonica. The Messinian interval exhibits a stable isotopic signature indicative of a brackish Lago Maretype setting and is then succeeded by Paratethyan ostracodes of Zanclean (i.e., early Pliocene age; Spezzaferri et al., Chap. 2, this volume).

The sedimentary and tectonic history of the Cyprus margin were expected to be quite different from that of the Eratosthenes Seamount as the two are located on opposing plates (see discussion in Mart and Robertson, Chap. 52, this volume). Drilling at Site 968 near the base of slope of the Cyprus margin did reveal such a contrast. Beneath a Pliocene-Pleistocene succession, more than $200 \mathrm{~m}$ of argillaceous sediments, interbedded with calcareous turbidites, were recovered. Shipboard analysis showed that microfossils in the lower part of the succession are entirely reworked, and include abundant brackishwater ostracodes and the benthic foraminifer Ammonia tepide; thus, a Messinian age is assigned to this interval. Other clues concerning the depositional setting include the presence of abundant clays (e.g., smectites) and kaolinite, together with scattered dolomite and local halite crystals. Several thin layers of detrital selenitic gypsum sands were also recovered, together with thin layers $(5 \mathrm{~cm})$ of fine-grained alabastrine gypsum within clay (Emeis, Robertson, Richter, et al., 1996).

Lithoclasts of pelagic chalk and basalt and other constituents within abundant turbidites, mainly within the Messinian interval, at Site 968 were derived from the Troodos ophiolite and its sedimentary cover in southern Cyprus (e.g., the Miocene Pakhna Formation; Eaton and Robertson, 1993). The turbidites are inferred to have accumulated in a large lake or inland sea. In general, lacustrine conditions are known to have prevailed widely during late Messinian time, especially in the Mediterranean and circum-Black Sea region (i.e., Lago Mare; Steininger and Rögl, 1984).The Messinian at Site 968 is dominated by dark anoxic muds, minor turbiditic silts, and sands that contain grains including pelagic limestone, chert, and ophiolitic rocks, that can only have been derived from the southern part of $\mathrm{Cy}$ prus (Robertson, Chap. 36, this volume).

Minor intercalations of clastic gypsum (i.e., gypsarenite) show evidence of local gravity reworking. Stable isotopic data $\left({ }^{18} \mathrm{O}\right.$ and $\left.{ }^{34} \mathrm{~S}\right)$ indicate that the gypsum accumulated under marine conditions and is isotopically similar to selenitic gypsum precipitated in present-day solar ponds (Blanc-Valleron et al., Chap. 34, this volume). The gypsum is associated with a monospecific nannoplankton flora, as observed in finely laminated (balatino-type) gypsum of upper Messinian age elsewhere in the Mediterranean (Rouchy, 1982). Evidence from southern Cyprus indicates that selenitic gypsum was redeposited toward depocenters, thus helping to explain the occurrence of reworked gypsum at Site 968.

Overall, the background dark muds are inferred to have accumulated under brackish conditions (i.e., Lago Mare). This interpretation is supported by the presence of foraminifers, gastropods, and ostracodes. The gypsum accumulated up paleoslope and was then reworked into a basin at Site 968 (Blanc-Valleron et al., Chap. 34, this volume). Similar Messinian evaporites are exposed onshore in the southern part of Cyprus (Orszag-Sperber et al., 1989; Robertson et al., 1995a). The lake was probably located within a precursor of the present Northern Trough (i.e., a deep-sea trench) that separates the Eratosthenes Seamount from Cyprus (Fig. 1).

During the Messinian, the Eratosthenes Seamount formed a topographically raised area marked by erosion and soil development. Site 967 to the north was located at greater depth, where local accumulation of gypsum and late Messinian lacustrine facies took place, possibly in small marginal lagoons, or lakes. An important question is whether the late Messinian Lago Mare facies at Sites 967 and 968 should be correlated and interpreted as occurring within the same basin. At present, the Messinian in Site 967 is located about 3000 mbsf, whereas Site 968 is located at about 2150 mbsf. If the two sites were originally part of the same Messinian lake, as is likely, about $1000 \mathrm{~m}$ of differential vertical motion between the two sites has taken place since the late Messinian. This large relative motion is indeed probable, based on the tectonic analysis of the Eratosthenes Seamount, as discussed in a later section of the paper. On the other hand, it is also possible (but less likely) that the Lago Mare facies at both sites accumulated in separate basins located at different topographic levels. Site 968 is currently located in a sediment-starved lower slope setting, whereas conditions in the late Messinian were clearly more basinal, with terrigenous turbidite deposition. Relative uplift of Site 968 apparently has taken place since late Messinian time. Also, micropaleontological evidence from Site 967 points to subsidence of Eratosthenes at Site 967 (see below). The facies evidence points to subsidence of the northern margin of the Eratosthenes Seamount at Site 967, coupled with uplift of the outer Cyprus margin at Site 968 during Pliocene-Pleistocene time at Site 968. This possibility is discussed below in a later section.

Site 968 possibly formed part of the northern edge of a large ( 25 $\mathrm{km}$ wide) hypersaline basin located between Eratosthenes and $\mathrm{Cy}-$ prus. This basin was located within what is interpreted as a subduction trench between these two areas. Much, or all, of this trench sedimentation was possibly later subducted in the Pliocene-Pleistocene time. This would explain why there is presently no evidence of thick evaporites between Cyprus and Eratosthenes, based on seismic data (Limonov et al., 1994).

In summary, sediments of inferred Messinian age on the Eratosthenes platform (Sites $965,967,968$ ) are thin or absent, whereas at Site 968, a hundreds-of-meters-thick succession of probable late Miocene, mainly lacustrine, facies (i.e., Lago Mare) is present. This confirms a contrast between Cyprus, located on the Eurasian plate, and Eratosthenes on the Africa plate.

\section{Early Pliocene}

All of the sites drilled during Leg 160 document the refilling of the Mediterranean at the end of the Messinian desiccation crisis (Hsü, Montadert, et al., 1978). Major et al. (Chap. 38, this volume) argue that this filling event was coupled with significant isostatic depres- 
sion of the seamount (i.e., hundreds of meters) leading to a rapid incoming of bathyal pelagic sediments. However, drilling during Leg 160 showed that conditions varied at individual sites. For example, at Site 965 , on the upper slope of the seamount, a thin $(6 \mathrm{~m})$ inferred Messinian interval contains rare, poorly preserved nannofossils of 3.5-6 Ma (late Miocene-early Pliocene age), suggesting that reworking took place associated with the marine transgression. In the vicinity, the base of the Pliocene at Site 965 is marked by a sharply defined, flat, seismic reflector, consistent with the presence of a strong lithology contrast between Miocene limestone below and weakly consolidated Pliocene fine-grained sediments above. A similar welldefined reflector is present at Site 967 farther north, where the interval between the early Pliocene and middle Eocene includes scattered clasts of pelagic chalk and limestone and, as noted earlier, reworked foraminifers of Eocene, Oligocene, and early Miocene age. This is in addition to long-ranging forms that span late Miocene or early Pliocene times. A source of both well-lithified and unlithified pelagic carbonate must thus have existed in the vicinity of Site 967.

Interbedded nannofossil muds and matrix-supported breccias ("mass-flow unit" or "paraconglomerate") were recovered at Site 966, the southernmost of the Eratosthenes drill sites (Fig. 2). The contact with the underlying Miocene limestone is sharp and planar, based on log evidence (Major et al., Chap. 38, this volume). In this area, the seismic character of the unconformity at the base of the Pliocene succession is much less distinct than in adjacent parts of the seamount.

Recovery was studied from four adjacent holes at Site 966, allowing detailed comparisons of successions of slightly differing thickness and facies (Robertson, Chap. 37, this volume). Biostratigraphic evidence, based on nannofossils and planktonic foraminifers, indicates an earliest Pliocene age for the matrix, and a late Miocene-early Pliocene age for the clasts (Emeis, Robertson, Richter, et al., 1996). The matrix is mainly nannofossil ooze mixed with silt-sized reworked carbonate, minor quartz, and terrigenous clay. The limestone clasts underwent extensive solution, followed by variable meteoric water cementation that presumably took place during the Messinian salinity crisis (Robertson, Chap. 36, this volume). The FMS data reveal very resistant clasts within a less resistant matrix. The clasts appear to become generally less abundant upward. The logs also suggest that the matrix-supported breccias are markedly dipping and cut by a fault. The presence of an organic-rich layer can be correlated with a strong peak in uranium (Major et al., Chap. 38, this volume).

The matrix-supported breccias are interpreted by Robertson (Chap. 37, this volume) as multiple debris flows, related to initial break-up of the Eratosthenes Seamount. The breccias could relate to faulting that triggered release of successive debris flows into a bathyal pelagic carbonate succession. Very similar matrix-supported breccias of similar age are known onshore in Cyprus (Follows and Robertson, 1990). Alternatively, Major et al. (Chap. 38, this volume) argue that this unit appears to thin toward the present rim of the seamount, based on their interpretation of the shipboard site survey data. They note that if this rim had exerted a fault control, then one would expect a thickening toward such a fault source area that they do not believe to be present. These authors instead suggest that the "paraconglomerate" formed by initial exposure of the seamount on land during the Messinian. In their view, penetration by rainwater induced solution and karstification to produce a unit of very irregular thickness, followed by repeated reworking under the influence of both terrestrial conditions and near-shore high-energy conditions to produce the final deposit. It is certainly true that subaerial exposure and karstification could have played a role in the creation of the highly porous clasts of Miocene limestone within the matrix-supported conglomerate. However, such clasts occur within bathyal nannofossil ooze of early Pliocene age, thus ruling out final accumulation in a near-shore setting. The clasts are mainly very angular, and only very rarely are clasts observed to be well rounded and waterworn (Emeis,
Robertson, Richter, et al., 1996). Also, the present fault-controlled rim of the seamount to the south is considered to be a Pliocene-Pleistocene feature (i.e., possibly quite recent) based on interpretation of high-resolution seismic data (Limonov et al., 1994), and thus may be unrelated to formation of the matrix-supported breccias. Numerous faults cut the plateau area of the Eratosthenes Seamount (Krasheninnikov et al., 1994; Limonov et al., 1994), but it is not possible to relate these faults directly to the source of the debris flows without geophysical evidence and further coring. During initial collapse the Eratosthenes Seamount is envisioned as being tilted, possibly giving rise to numerous closely spaced faults, creating a topography favorable to shedding of debris flows into a transgressive sea.

At Site 968, at the base of the Cyprus slope, an entirely different Miocene-Pliocene transition is documented. An upward transition to early Pliocene sediments is marked by an incoming of age-diagnostic nannofossils and planktonic foraminifers. Input of calcareous turbidites derived from Cyprus continued with no obvious break, but became less voluminous upward. Site 968 was already located well below eustatic sea-level in the Messinian, and deep-marine sedimentation ensued in the early Pliocene following marine transgression, with no observable tectonic disruption.

The late Messinian at Site 968 is dominated by relatively homogenous clays, with low carbonate contents, and relatively depleted $\delta^{18} \mathrm{O}$ and $\delta^{13} \mathrm{C}$ values. Detailed isotopic study of the MessinianPliocene boundary interval illustrates a change from brackish to fully open-marine conditions (Pierre et al., Chap. 1, this volume). By contrast, the early Pliocene was marked by more calcareous bioturbated sediments with enriched $\delta^{18} \mathrm{O}$ and $\delta^{13} \mathrm{C}$ signatures for the carbonate fraction (Pierre et al., Chap. 1, this volume). The Messinian-Pliocene boundary at Site 968 is shows a marked increase in terrigenous sediment input and an increase in carbonate content that were associated with the marine transgression. The presence of kaolinite-smectite clay assemblages in the overlying lower Pliocene part of the succession suggests a relatively warm and wet climate, as inferred for localized upper Messinian lacustrine sediments (Lago Mare) and paleosols in southwest Cyprus (Rouchy, 1982).

\section{Pliocene-Pleistocene}

At each of the four sites drilled, the Pliocene and Pleistocene successions record deep-marine accumulation. The Eratosthenes Seamount and its flanks are now at water depths ranging from 700 to $2900 \mathrm{~m}$. Much of this subsidence apparently took place rapidly, as the lowest part of the early Pliocene succession already contains bathyal microfossils, estimated to have accumulated at depths of 1800-200 $\mathrm{m}$. Further deepening took place after the late Pliocene, at Site 967, as benthic foraminifers there indicate upward deepening to around 200-3000 m (Emeis, Robertson, Richter, et al., 1996; S. Spezzaferri, pers. comm., 1995). Thin, steel-gray mud turbidites in the uppermost part of the succession at the base of the Eratosthenes Seamount slope (Site 967) were deposited from dilute gravity flows that contained mica and biotite, and other minerals for which the Nile River is the likely origin. The lower Pliocene hemipelagic sediments include numerous intercalations of well-preserved sapropels that are discussed elsewhere in this volume (Kroon et al., Chap. 14, this volume). Preliminary shipboard paleontological analysis suggested that a hiatus of up to $0.5 \mathrm{~m}$.y. existed within the late Pliocene-early Pleistocene time interval at Site 967 . However, detailed postcruise stable isotopic analysis of planktonic foraminifers has since shown that no such hiatus actually exists (Kroon et al., Chap. 14, this volume). At Site 966, sedimentation rates were extremely slow (1-2 m/m.y.), but no paleontological zones are missing (Emeis, Robertson, Richter, et al., 1996). The absence of a hiatus at Site 966 is unsurprising as the Pliocene and Pleistocene succession accumulated on the submerged plateau area of the seamount. However, the continuity of PliocenePleistocene sedimentation at Site 967 on the lower slope is extraordi- 
nary, as the site survey seismic and coring data clearly indicate that the site is located near the crest of a large (kilometer sized) anticlinal feature that developed during Pliocene-Pliocene time, and is probably still active (Limonov et al., 1994; Robertson et al., 1995c).

\section{DISCUSSION}

Having summarized the main results of drilling, I will devote the latter part of this paper to discussing some specific sedimentary and tectonic processes that affected the Eratosthenes Seamount.

\section{Structural History of Eratosthenes Seamount}

In this section, the evidence for the nature and orientation of strain that affected the Eratosthenes Seamount through time is considered. In many cases, the bedding dip and core lamination were noted to be slightly inclined with respect to horizontal, but this information is of little value as the cores could not be oriented to their original positions. However, the FMS allows dip directions in different parts of the successions drilled to be compared (Major et al., Chap. 38, this volume; Flecker et al., Chap. 40, this volume). Analysis carried out by Flecker et al. (Chap. 40, this volume) revealed the following main trends in dip direction: late Aptian sediments in Hole 967E dip toward the south-southeastward, whereas overlying Late Cretaceous lithologies show no single dip direction. Mid-Eocene pelagic sedimentary rocks in Hole 966F dip northwestward, whereas similar lithologies of Oligocene age in Hole 967F show generally bimodal, north-south directions. Miocene strata in Hole 965A dip toward the northwest, whereas dips of Miocene sediments as Site 966 are mainly to the northeast. A slightly less detailed analysis carried out by Major et al. (Chap. 38, this volume) on the FMS-derived dip data produced generally similar results.

In addition, numerous faults and other deformation features (e.g., flattened burrows) were observed within lithified, mainly prePliocene parts of the successions drilled. Using the cove recovery, estimates could be made of strain based on flattening of bioclasts and other objects. The results suggest that a linear increase in vertical shortening occurred from the Eocene through the Miocene to the Pliocene at Sites 966 and 967 (Flecker et al., Chap. 40, this volume).

Most of the fractures observed in FMS images at Sites 965 and 966 are high-angle features that clearly cut low-angle features interpreted as depositional structures. The fragmentary nature of the recovery and the absence of a means of reliably orienting the cores effectively prevented interpretation of the high-angle structures in terms of stress directions (Emeis, Robertson, Richter, et al., 1996; Kopf and Flecker, 1996). However, the FMS log data provide a means of independently determining the nature and orientation of strain. Using these data, Flecker et al. (Chap. 40, this volume) identify east-west-trending fractures at Sites 966 and 965 . For Hole 965A, an additional set of north-south fractures is recognized. Late Turonian-Maastrichtian lithologies at Hole 967E show two main orientations: one striking northeast-southwest and dipping mainly to the southeast, and the other striking northwest-southeast and dipping mainly to the northeast.

The question then arises as to whether the dip patterns and fault trends were developed at different times during the Mesozoic-Tertiary development of the Eratosthenes Seamount or whether they mainly relate to the tectonic disruption known to affect the area during Pliocene-Pleistocene time from geophysical results. Flecker et al. (Chap. 40, this volume) compare the orientations of fractures in different parts of the succession and suggest that where a fracture direction occurs in a lower, but not in a higher, part of a succession, this indicates that the lower unit was faulted in a particular stress field, followed by deposition and then further faulting in a different stress field. The change of fracture pattern and depositional dip commonly occur across depositional hiatuses that were possibly tectonically controlled. For example, a hiatus from Maastrichtian to Oligocene in Hole 967E (Premoli-Silva et al., Chap. 30, this volume) could correspond to the time of a phase of fracturing. Also, clear changes in fracture orientation occur between the Paleogene and Miocene at Sites 965 and 966, and are also marked by changes in bedding direction and evidence of uplift, as shown by the sedimentary facies. Flecker et al. (Chap. 40, this volume) interpret the varying dip and fracture data to indicate that the different sites drilled were located on separate fault blocks within the Eratosthenes Seamount that experienced differential movements at various times. An alternative interpretation, acknowledged by Flecker et al. (Chap. 40, this volume) is that most, or all, of the changes in dip and fracture orientation occurred contemporaneously in Pliocene-Pleistocene time. If so, the apparent contrasts in inferred dip and fracture orientations would be the result of inherent variability in faulting, vagaries of fault occurrence and coring, and statistical uncertainties of sampling.

One must therefore ask, do the strain patterns determined from FMS show similarities with the modern instantaneous stress field and those suggested by geophysical observations? Adequate quality data on instantaneous stress directions were obtained from breakouts in the deep CY-4 borehole through the Troodos ophiolite in Cyprus, supplemented by hydraulic fracturing stress measurements (Haimson et al., 1990). Breakouts are assumed to record the direction of maximum principal horizontal stress. In Cyprus, breakouts are oriented near $\mathrm{N} 65^{\circ} \mathrm{E}$. The results indicate either normal or strike-slip stress conditions, and could be explained by left-lateral strike slip along the Africa-Eurasia plate boundary in this region, as inferred from regional geophysical studies (Kempler, 1993; Ben-Avraham et al., 1995).

Jurado-Rodríguez and Brudy (Chap. 41, this volume) attempt an analysis of break-out data (i.e., borehole enlargement) for the holes drilled in the Eratosthenes Seamount, combined with analysis of vertical drilling-induced fractures. The orientation of the maximum principal horizontal stress in Hole 967E, located in the lower northern slope of the seamount, is estimated to lie at $\mathrm{N} 30^{\circ} \mathrm{E}$; for Hole $965 \mathrm{~A}$ in the upper slope at $\mathrm{N} 170^{\circ} \mathrm{E}$, and for Hole $966 \mathrm{~F}$, at $\mathrm{N} 50^{\circ} \mathrm{E}$. Interpretation of these results is difficult as the holes are relatively shallow (other than Hole 967E) and hole conditions were generally poor. The crust drilled at Site 967 is interpreted as being thrust generally southward over the northern margin of the Eratosthenes Seamount $\left(\mathrm{Li}^{-}\right.$ monov et al., 1994; see Fig. 6). Thus, the orientation of the maximum principal stress direction in Hole 967E could reflect this overthrusting, related to collision of the Eratosthenes Seamount with Cyprus. The upper northern slope area of the Eratosthenes Seamount has undergone down-to-the-north normal faulting, that may well be still active, and thus the maximum principal horizontal stress would be expected to be oriented nearly east-west, as inferred. The seamount plateau area further south has experienced nearly east-northeast-westsouthwest oriented normal faulting, that is probably still active. The maximum principal horizontal stress could be expected to be oriented at right angles to this direction, which is not observed. However, the direction $\left(\mathrm{N} 50^{\circ} \mathrm{E}\right)$ is similar to that inferred for southern Cyprus (Haimson et al., 1990), and interpreted in terms of left-lateral strike slip. The Eratosthenes Seamount is located close to a segment of the Africa-Eurasia plate boundary undergoing left-lateral strike-slip deformation that may also be affecting the Eratosthenes Seamount.

Strain patterns can also be inferred from geophysical evidence of deformation that affected the Eratosthenes Seamount and adjacent areas. The plateau area of the seamount is dominated by nearly eastwest oriented extensional faults. The upper northern slopes of the seamount are cut by numerous approximately east-west-trending normal faults that step down to the north. This faulting is associated with gravity collapse and soft-sediment slumping. In addition, the lower northern slope of the Eratosthenes Seamount is marked by compressional thrusting and development of a west-southwest- to east-southeast-trending ridge, suggesting that the compression that 
gave rise to this structure was oriented generally at right angles to this direction. The Eratosthenes Seamount is also separated from the Northern Trough (adjacent to the Cyprus margin) by a northwarddipping fault, interpreted as a thrust fault (Limonov et al., 1994; Krasheninnikov et al., 1994; Robertson et al., 1995c). The available geophysical evidence thus suggests approximately east-west faulting in the south (plateau area), and compressional thrusting in the north (lower northern slopes of Eratosthenes) during Pliocene-Pleistocene time (although an oblique-slip component of deformation cannot be excluded). This, however, may not represent the present-day instantaneous stress direction, as recorded in the borehole breakouts.

Taking together all the deformation data together in the regional context it can be concluded that (1) The Eratosthenes Seamount is today probably influenced mainly by east-west strike-slip related to westward escape of Anatolia to the north, as is confirmed by global positioning system measurements for the wider region (Reilinger et al., 1997). (2) During Pliocene-Pleistocene time as a whole, the stress was approximately oriented north-south, giving rise to near east-west oriented thrusting along the northern margin of the seamount, and high-angle extensional faulting of the plateau area. The high-angle faulting is interpreted as a flexural response to thrust loading (see below). The possible cause of this difference in structural style between these two areas of the seamount is discussed farther below. (3) During Miocene and earlier time the seamount experienced relatively minor tectonic instability associated with tilting and sedimentary hiatuses, triggered by regional changes in stress field throughout the easternmost Mediterranean region. These include probable rifting in the Early Cretaceous, convergent plate tectonics in the Late Cretaceousearly Tertiary (e.g., ophiolite emplacement farther north), and uplift of the Eratosthenes Seamount before Miocene time (possible reasons for this will be discussed below). (4) At present, the structural data are inadequate to separate unambiguously the fracture populations developed during each of the above three inferred stages of development of the Eratosthenes Seamount.

\section{Subsidence and Uplift History of the Eratosthenes Seamount}

Analysis of decompacted subsidence curves is a powerful method to determine basin history, when compared with curves from known tectonic settings. As shown by Whiting (Chap. 39, this volume), the subsidence record for the Cretaceous to early Oligocene time interval implies progressive subsidence at a gradually decreasing rate; this is typical of subsidence related to thermal decay of a passive margin (see Whiting, Chap. 39, this volume, for literature review). Water depths at Site 967 increased from neritic in the pre-Aptian basal succession to lower epibathyal-upper mesobathyal in the Late Cretaceous-early Tertiary, accompanied by a decrease in sedimentation rate (Emeis, Robertson, Richter, et al., 1996). Unfortunately, resolution is limited by the presence of important hiatuses (Premoli-Silva et al., Chap. 30, this volume). The presence of middle Eocene sediments at Site 966 suggests that a similar subsidence history affected both Sites 967 and 966 until the Miocene. The subsidence data also suggest that uplift of about $1 \mathrm{~km}$ took place before the onset of Miocene shallow-water carbonate deposition, although the exact time of onset and duration of this uplift remains unconstrained. Following the late Miocene, rapid subsidence of the Eratosthenes Seamount took place in the early Pliocene and continued into the late Pliocene-Pleistocene (Whiting, Chap. 39, this volume).

The cause of the Miocene uplift is problematic. Possible explanations mainly relate to the possible timing of subduction and collision of the Eratosthenes Seamount with the Cyprus active margin. The main alternatives revolve round the idea that the Eratosthenes Seamount was associated in some way with a northward-dipping destructive plate boundary around Miocene time; this was well established, incipient, or advanced to a collisional stage in different inter- pretations, and there are several possible causes of uplift unrelated to such a plate tectonic setting. Some specific hypotheses are as follows (Fig. 3):

1. Northward-dipping subduction was already active before Miocene time. The subducting slab became unstable and broke off, resulting in flexural uplift of the overlying plate (B. Whiting, pers. comm., 1997; Fig. 3A). Although there is no direct evidence of Oligocene subduction in the easternmost Mediterranean area, this possibility cannot be ruled out on the basis of the Leg 160 data. However, to achieve flexural uplift, Eratosthenes would already have needed to be located close to the trench (about $50 \mathrm{~km}$ ) by the time uplift took place. Also, this mechanism does not provide an explanation of apparently contemporaneous folding and thrusting in southern Cyprus, as discussed in the next section of this paper.

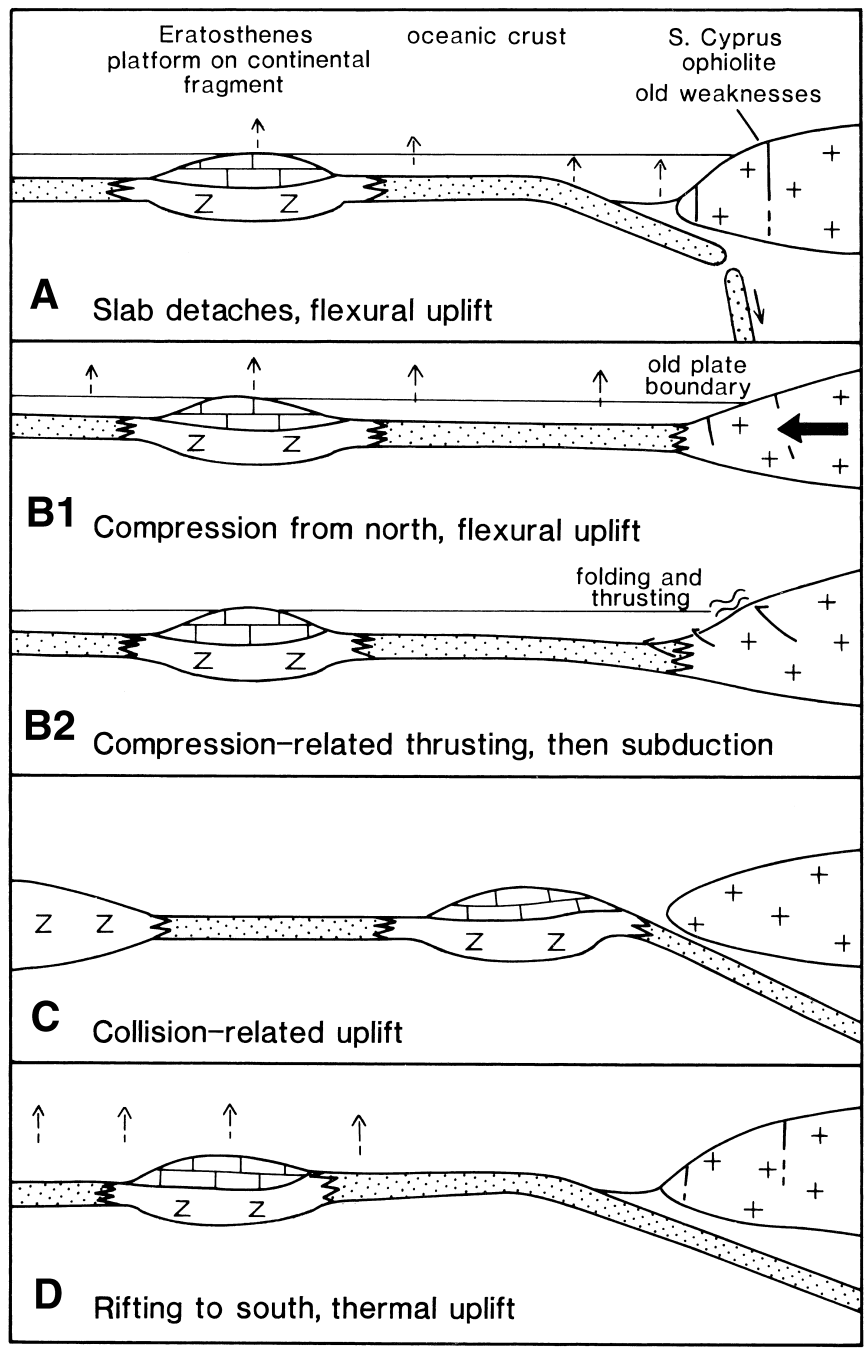

Figure 3. Alternative models to explain the Miocene uplift of the Eratosthenes Seamount. The seamount was uplifted by $\sim 1 \mathrm{~km}$ between the Oligocene and Miocene. A. Pre-existing northward subduction, followed by slab detachment and flexural uplift. B. Uplift caused by initiation of the present northward-dipping subduction zone, related to regional compression directed from the north. The crust was first flexed (B1) and then failed (B2), marked by folding and thrusting in southern Cyprus and initiation of subduction. $\mathbf{C}$. Uplift related to collision of Eratosthenes with the Cyprus active margin. D. Uplift from thermal, rift-related effects to the south. Option B is favored here. 
2. Uplift was a consequence of regional compression related to the onset of northward subduction to the south of Cyprus (i.e., formation of the present subduction zone; Fig. 3B). The nature of crustal deformation associated with the onset of subduction remains poorly understood, but is clear that large amounts of energy must be involved, and that deformation over an initially broad area (several hundred kilometers) is to be expected. This possibility is favored here as it also explains the evidence of apparently coeval uplift of Cyprus, specifically southwarddirected folding and thrusting in southern Cyprus (see below).

3. Uplift was related to compression caused by collision of the Eratosthenes Seamount with the Cyprus active margin to the north, following a period of northward subduction (Mart, 1997; Y. Mart, pers. comm., 1997; Fig. 3C). This model is unlikely for the following reasons: (1) Collision would result in flexural loading and collapse rather than regional uplift during the Miocene. This did indeed affect the seamount, but not until Pliocene and Pleistocene time, up to 10 m.y. later; (2) There is no evidence that compressional deformation affected the Eratosthenes Miocene successions, as expected in a collisional setting. If Cyprus was thrust over the Eratosthenes Seamount as in this model, some initial flexural uplift might have taken place, but this would soon be followed by collapse to form a foredeep; this is not observed.

4. Uplift was related to hot-spot activity associated with rifting (Fig. 3D), conceivably the opening of the Gulf of Suez farther south. This can, however, be ruled out as there is no evidence of regional high heat flow or volcanism in the Cyprus-Eratosthenes area in Neogene time.

5. Uplift relates to some other setting of compressional deformation (B. Whiting, pers. comm., 1997). An obvious candidate would be southward thrusting from a suture represented by the Kyrenia Range in the north of Cyprus. However, compressional deformation was not active there during the late Oligoceneearly Miocene time in question and, in any case, was northward rather than southward directed when active during the
Tertiary (see Robertson, Chap. 54, this volume, for literature review).

\section{Evidence of Miocene Uplift and Deformation in Southern Cyprus}

An additional constraint on tectonic models attempting to explain the mid-Tertiary uplift of the Eratosthenes Seamount is the nature of southward-directed compressional deformation that affected southern Cyprus in early Miocene time, and the uplift of this area as a whole.

Deep-sea pelagic chalk deposition in southern Cyprus (Lefkara Formation) was followed by upward shallowing by the beginning of Miocene time, followed by accumulation of relatively more shallowwater sediments (Pakhna Formation), together with initial input of clastic sediment derived from the ophiolitic basement in some areas (Eaton, 1987). The shoaling was abrupt and affected the whole of southern Cyprus. It has been interpreted as the result of regional tectonic uplift rather than eustatic sea level fall (Robertson et al., 1991b).

There is also evidence of important early Miocene uplift and a compressional event in southern Cyprus (the Yerasa Fold and Thrust Belt), known from several sub-parallel lineaments that can be traced onshore and just offshore (Fig. 4). The Yerasa Fold and Thrust Belt is restricted to a narrow linear belt several kilometers wide adjacent to the ophiolitic basement of the Limassol Forest Block (Morel, 1960; Eaton and Robertson, 1993; Robertson et al., 1991b; Gass et al., 1994). The zone of deformation is most intense in the west and extends $\sim 30 \mathrm{~km}$ toward the coast as a broad anticlinal feature within Paleogene sediments. It can also be traced offshore on shallow seismic profiles (McCallum et al., 1993).

Thrusts within the Yerasa Fold and Thrust Belt clearly root within the Limassol Forest Ophiolite to the north (Fig. 4). The thrusts dip north-northeast at $30^{\circ}$, or more. Local field relations reveal microgabbro thrust over lava breccia, and overturning of Late Cretaceous basalt, metalliferous sediments, and radiolarite. Pillow lavas are also locally thrust over Paleogene sediments of the Lefkara Formation.
Figure 4. Role of Miocene deformation in southern Cyprus. A. Geological sketch map of southern Cyprus showing southward-directed deformation of the southern margin of the Late Cretaceous ophiolite and adjacent sedimentary cover (Yerasa Fold and Trust Belt and other lineaments). B. Cross-section of the Yerasa Fold and Trust Belt. Note the southwarddirected thrusting of ophiolite over the sedimentary cover.
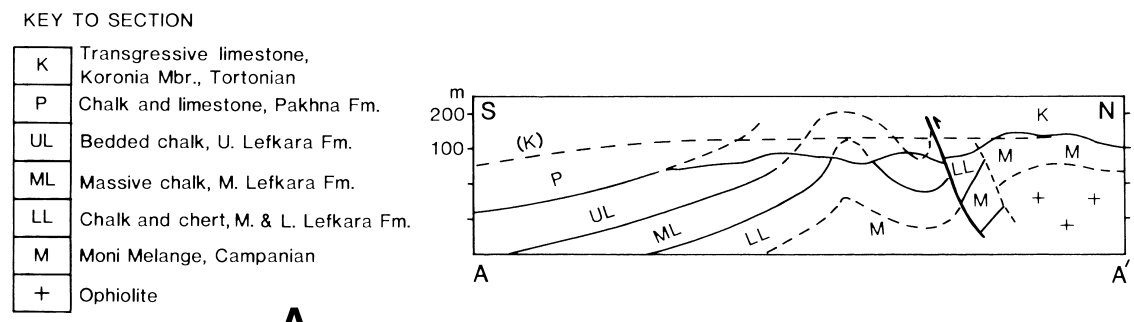

A

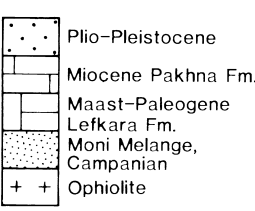

B

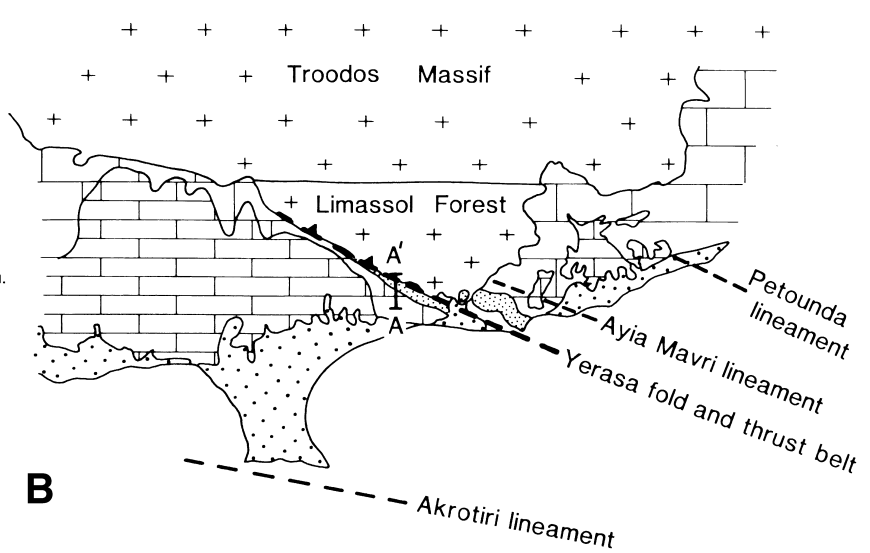


Locally, kinematic indicators suggest top-to-the-south displacement (but do not indicate evidence of regional strike-slip). South of the Limassol Forest Block, the ophiolite is overlain by the Campanian Moni Melange, comprising diverse blocks in a clay matrix, locally with a strong north-dipping foliation. To the west the Moni Melange wedges out and, there, the overlying Paleogene pelagic carbonates (Lefkara Formation) are highly folded and affected by thrusting. By contrast, deformation is mainly confined to folding in the southeast, where the Moni Melange is thicker. Folding is tight, with steeply northward-dipping axial planes, with locally overturned southern limbs. Axial planar pressure solution cleavage is well developed, together with steep northward-dipping reverse faults.

A further important west-northwest- to east-southeast-trending lineament runs through the southern tip of the Akrotiri Peninsula and offshore, based on borehole and offshore shallow seismic evidence (McCallum et al., 1993). An additional less well-defined lineament (Ayia Mavri lineament) of similar orientation is inferred to lie within sediments to the northeast of the Yerasa lineament (Eaton and Robertson, 1993).

The Miocene tectonically active lineaments are restricted to southern Cyprus and areas directly offshore and are not recognized in other parts of Cyprus (i.e., north of the Troodos ophiolite). This implies that the driving force of compression was located offshore from southern Cyprus, suggesting a possible link with the tectonic history of the Eratosthenes Seamount. The time of uplift of Eratosthenes Seamount before shallow-water carbonate deposition approximately corresponds to the time of an important phase of the southward thrusting and folding in the south of Cyprus, principally the Yerasa Fold and Thrust Belt, and it is likely that the two are related. If correct, this link would tend to rule out models of early Miocene Eratosthenes uplift that do not invoke compression in southern Cyprus (i.e., detachment of an older slab; flexural subsidence; thermal uplift).

Eaton and Robertson (1993) suggested that the deformation might be related to the onset of northward subduction. In this hypothesis, after the emplacement of the Kyrenia Range in the north of Cyprus, the only substantial oceanic crust remaining in the gap between Africa and Eurasia lay to the south of Cyprus. Continuing convergence resulted in arching (i.e., flexure) of the area to the south of a relatively rigid Troodos ophiolitic slab, causing regional uplift of the Eratosthenes Seamount $(\sim 1 \mathrm{~km})$, then still located south of its present position, together with surrounding areas. With continued convergence, the crust failed along pre-existing zones of crustal weakness within southern Cyprus to form the Yerasa Fold and Thrust Belt, and other lineaments. Farther south, a northward-dipping subduction zone was activated as a precursor to the present-day active margin. This was followed by steady-state northward subduction in the Miocene during which time (up to 10 m.y.) the Eratosthenes Seamount gradually subsided and was overlain by Miocene shallow-water carbonates. The deformed lineaments in southern Cyprus and onshore were transgressed by late Miocene shallow-water carbonates, including fringing reefs (after the late Langhian). By the beginning of the Pliocene, or slightly earlier (see later), the Eratosthenes began to collide with the Cyprus active margin for the first time.

\section{Role of Isostasy on Vertical Motion History}

The overall thesis put forward in this paper is that the vertical motion history (uplift and subsidence) of the Eratosthenes Seamount is mainly a consequence of its plate evolution. However, before Leg 160 drilling, a common view was that the Eratosthenes Seamount is now an essentially tectonically "dead" feature. It was either located on the North African plate far from a plate boundary, or if actively involved in plate tectonics, any deformation took place at an early stage, during Miocene time or earlier (see Mart and Robertson, Chap. 52, this volume, for discussion). In this volume (Chap. 38), Major et al. carry forward the view that Eratosthenes experienced only minor tectonic activity in Pliocene-Pleistocene time. They argue that most of the post-Miocene subsidence of the seamount can be explained by isostatic effects, with only very minor tectonic influence.

Major et al. (Chap. 38, this volume) envisage the Eratosthenes Seamount as a bathymetric feature rising from a deep basin with a thick sediment cover. They carry out unidimensional Airy backstripping, and compute the relative subsidence history for a number of time slices (top Messinian, basal Messinian, base of Neogene, present day). They extend an existing Airy-type backstripping model for the adjacent Levant margin (Tibor et al., 1992) westward to the Eratosthenes Seamount and argue that the approximately 800-m water depth of the crest of the seamount could be explained purely by isostatic effects related to post-Messinian reflooding of the Mediterranean, and the effect of crustal loading by Messinian and PliocenePleistocene sediment that accumulated within the surrounding deep basin. Major et al. (Chap. 38, this volume) argue that sedimentation rates greatly increased in the Messinian because of lowered base level of erosion and evaporite precipitation during the salinity crisis (Hsü et al., 1973). Flooding of the Mediterranean at the beginning of the Pliocene caused isostatic subsidence that could explain the appearance of lower Pliocene bathyal pelagic sediments above the subaerial Messinian on the seamount. In this interpretation, tectonic effects on subsidence are relegated to minor faulting of the northern margin of the seamount

Isostatic effects alone are, however, very unlikely to explain the deep submergence of the Eratosthenes Seamount after the Messinian for the following reasons: (1) The seamount was near sea level during the Miocene (pre-Messinian). A fall in sea level, followed by a rise would return the seamount to its previous equilibrium position and would not explain the present $800 \mathrm{~m}$ depth of the plateau area. (2) The top of the then-Miocene interval on the upper northern slope of the Eratosthenes Seamount (Site 955) is currently at about $1530 \mathrm{mbsf}$, much more than can be accounted for by isostatic subsidence caused by reflooding of the Mediterranean, combined with the additional loading effect of Messinian sediments. (3) The thin Miocene interval at Site 967 on the lower Eratosthenes slope, although lacking depth control on accumulation, is now at about $2670 \mathrm{mbsf}$, suggesting that very drastic subsidence has taken place. (4) Micropaleontological evidence supports increased subsidence of the seamount in late Pliocene-Pleistocene time that cannot be explained by an isostatic process. Airy isostasy assumes local compensation, whereas flexure involves broader regional compensation that must also be taken into account. By contrast with this interpretation of only minor tectonic effects, the available geophysical evidence indicates that Eratosthenes is strongly active and is being thrust beneath the Cyprus margin to the north (Limonov et al., 1994; Krasheninnikov et al., 1994; Fig. 5A). The control of subsidence of the Eratosthenes Seamount was dominantly tectonic controlled flexure, rather than isostatic, or related to sediment loading. On the other hand, it is accepted that isostatic depression related to reflooding of the Mediterranean after the Messinian salinity crisis could help explain the apparent rapid submergence of the seamount to bathyal depths in early Pliocene time. It is also accepted that deposition in the Messinian accentuated downflexure of Eratosthenes Seamount in the Pliocene-Pleistocene.

\section{Eratosthenes as a Quadrilateral Graben Structure?}

Before these drilling data and other recent geophysical results became available, Kempler (1993) analyzed the then-available seismic and geophysical data (mainly gravity and magnetic) and proposed that the Eratosthenes Seamount could be considered as a tectonic high located within a quadrilateral-shaped graben structure (Fig. 5B) This structure developed during Tertiary time, especially in the Neogene, and was more recently involved in collision following northward subduction along a plate boundary to the south of Cyprus. Kempler (Chap. 53, this volume) reiterates her previous interpreta- 

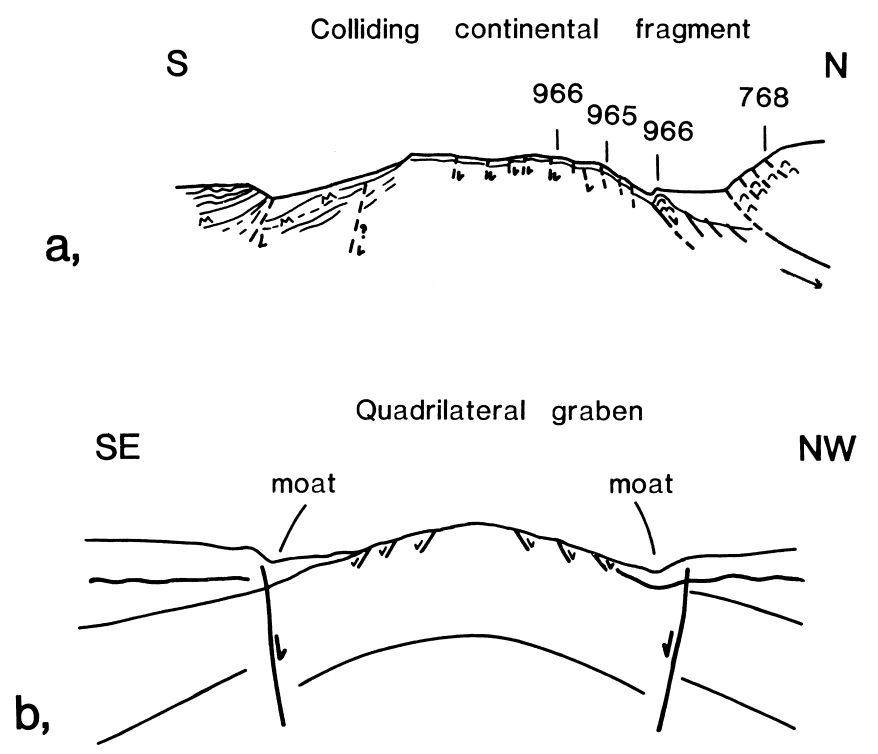

Figure 5. Alternative tectonic models for the Eratosthenes Seamount. Both assume the seamount is thinned continental crust associated with basic intrusions or extrusions at depth. A. Seamount as a crustal fragment in the processes of collision with and underthrusting beneath Cyprus; also with evidence of southward underthrusting (Limonov et al., 1994; Robertson et al., 1995a). B. Seamount as a quadrilateral graben structure bounded by inward-dipping long-lived normal faults (Kempler, 1993, Chap. 53, this volume). Interpretation (A) is favored here.

tion and concludes that her model can also explain the Leg 160 results and the recent geophysical data.

Kempler (1993; Chap. 53, this volume) argues that the Eratosthenes Seamount is flanked by high-angle normal faults (with throws of hundreds of meters) that define a "moat" related to a quadrilateral graben structure. This structure is superimposed on a largerscale Eratosthenes structural high. In this model, bounding normal faults played a key role in controlling important vertical tectonic movements, specifically subsidence after the Messinian. A "moat" formed by downfaulting of an area enclosed by steep faults bordering the rim of the seamount. Marginal faults are shown as dipping inward toward the Eratosthenes along both the northern and southern margins (Fig. 5B). The seamount first rose, then sank to form the surrounding "moat." The inferred normal faults were thought to displace a deep reflector by about $500 \mathrm{~m}$. Strike-slip faulting was thought to play a significant role. Exposed faults on the crestal area of the seamount were seen as probably not being active since they did not appear to cut the surrounding "moat." Kempler (1993, Chap. 53, this volume) envisions the seamount as now being in collision with $\mathrm{Cy}-$ prus active margin to the north.

Leg 160 drilling has confirmed some of Kempler's (1993; Chap. 53, this volume) views concerning the Eratosthenes Seamount, notably its affinity with North Africa and the Levant; the presence of a Messinian high, and an absence of compressional deformation at least beneath the Eratosthenes plateau area. The core and log data do indeed indicate the presence of numerous high-angle faults at the Eratosthenes sites drilled; some of these are demonstrably normal faults (Kopf and Flecker, 1996). However, the concept of the Eratosthenes Seamount as a structural high within a quadrilateral graben bounded by high-angle normal faults is questionable for the following reasons: (1) The Leg 160 site survey data (Limonov et al., 1994) and other recently acquired seismic data (Krasheninnikov et al., 1994) indicate that Eratosthenes dips northward beneath Cyprus), rather than being bounded by major high-angle normal faults. (2) The site survey data (Limonov et al., 1994) also suggest that the southern margin of the Eratosthenes Seamount dips beneath the Levantine Basin, again without evidence of high-angle normal faults. (3) Moatlike faultbounded basins are not seismically imaged around the western, or eastern margins of the seamount and no convincing evidence of inward-dipping high-angle faults is observed on seismic profiles. Moatlike basins do exists around the northern and southern margins, but these are alternatively interpreted as the result of plate convergence. (4) Site 967 on the lower slope of the seamount is located within a "moat," yet this was a setting of low net sedimentation in Miocene time, rather than basinal accumulation, possibly because it was then in a slope setting (Emeis, Robertson, Richter, et al., 1996). Normal faults, some of which are still active, imaged on the Eratosthenes plateau area and on the northern slope of the seamount, are alternatively interpreted as the result of flexural loading during the Pliocene and Pleistocene (Emeis, Robertson, Richter, et al., 1996; Fig. 5A). In summary, the concept of Eratosthenes surrounded as an quadrilateral graben structure bordered by related sediment moats is not supported by the Leg 160-related results.

\section{Role of Flexure-Induced Subsidence}

The collision of the Eratosthenes Seamount can be compared with the development of foredeeps where thrust units are emplaced onto continental crust (e.g., Beaumont, 1981; Stockmal et al., 1986). The Eratosthenes Seamount is interpreted as evolving into a foredeep related to collision with the Cyprus active margin. The upward passage from shallow-water carbonates to deep-water hemipelagic and terrigenous sediments can be compared with that observed in many foreland basin settings. For example, a trend from shallow- to deep-water sediments is seen in many foreland basin settings related to thrust and nappe emplacement (e.g., South Appalachians; Whiting and Thomas, 1994). Some of these foredeeps are related to ophiolite emplacement (e.g., in Oman; Robertson, 1987). Such sequences may end up as accreted slices in subduction complexes, as in the Tethyan area and elsewhere (see Robertson, 1994, for additional examples). In the case of the Eratosthenes Seamount, a marked increase in subsidence rate took place during late Pliocene-Pleistocene time, as in typical of foreland basin settings (Whiting, Chap. 39, this volume).

Important nearly east-west-trending extensional faults transect the Eratosthenes plateau area. Some of these are clearly dilational and appear to be presently active (Limonov et al., 1994; Krasheninnikov et al., 1994). In a simple flexural model of foredeep development related to advance of a thrust load, a forebulge should be generated followed by collapse to form a foredeep, without related extensional faulting. However, studies of some recent, active foreland basin areas have failed to confirm the importance of a forebulge (e.g., Indonesian area; Harris, 1991). On the other hand geological studies of well exposed ancient foreland basins show that the footwall commonly experiences high-angle faulting before and during foredeep sedimentation. Examples include the Hyblean-Malta Plateau (Gardiner et al., 1994); the Newfoundland Iapetus (Stenzel et al., 1990) and, nearer to Eratosthenes, Miocene basins of southern Turkey (Flecker et al., in press). The probable cause of such faulting is that, rather than producing a flexural bulge, the crust is faulted along pre-existing zones of crustal weakness, where present. The structure of the Eratosthenes Seamount is thus highly relevant to understanding of mechanisms of foredeep development.

\section{Significance of Eratosthenes Drilling for Accretionary Processes}

Seismic evidence suggests that a slice of limestone $\sim 1 \mathrm{~km}$ thick is being detached from the Eratosthenes Seamount and thrust southward related to northward thrusting beneath Cyprus (Limonov et al., 
1994; Figs. 6, 7B, 8). Interpretation of the seismic data (Figs. 6, 7B) indicates the presence of a small ridge at the base of the lower slope of the Eratosthenes Seamount at Site 967. This ridge is underlain by a northward-dipping fault zone that is interpreted as a reverse fault or thrust. Before Leg 160 it was hypothesized that this ridge is in the process of tectonic detachment from the Eratosthenes Seamount (Limonov et al., 1994; Robertson et al., 1997). The underlying fault represents the leading edge of an associated zone of compression.

An objective of drilling at Site 967 was to test if there is any evidence of such a zone of reverse faulting. It was hoped to drill through a décollement at a depth of about $550 \mathrm{~m}$. In the event, drilling reached the maximum permitted depth $(600 \mathrm{~m})$, but did not reach a décollement. This was probably because previous depth estimates did not take into account the presence of a thick limestone succession with relatively high seismic velocities. Drilling terminated in a unit of tectonically brecciated limestones, suggestive of proximity to a major fault zone, although the nature of this fault remains unknown (Emeis, Robertson, Richter, et al., 1996). Thin-section study has revealed abundant evidence of breccia textures that relate to in situ tectonic fragmentation, rather than to sedimentary reworking. Although of poor quality, the FMS data also indicate the presence of breccia-like fragments in the borehole wall (Major et al., Chap. 38, this volume).

Although the existence of a décollement could not be confirmed as drilling did not reach deeply enough, a possible history of thrust- disruption of the base of the northerly slope of the Eratosthenes Seamount can be inferred from the seismic evidence alone. The faulting must be relatively recent, since Pliocene-Pleistocene sediments that form an uplifted ridge at the base of the slope are clearly seen to be deformed on seismic profiles. Also, the ridge has a small sedimentary basin ponded against it to the south (Fig. 6). This basin is also well imaged on deep-tow high-resolution seismic profiles (Limonov et al., 1994) and can be seen to be deformed by numerous upright folds, with estimated wavelengths of only a few meters. The folds are interpreted to result from shortening of the sedimentary basin fill, associated with contemporaneous movement on the upthrust ridge to the south. Reverse faults are also imaged directly to the south, on the lower slope of the Eratosthenes Seamount.

\section{Significance of Eratosthenes for Melanges in Orogenic Belts}

By the time mountains begin to emerge, collisional processes are already well advanced and thus the early stages of crustal deformation can usually only be explored beneath the sea. Drilling on the Eratosthenes Seamount has provided some of the first direct evidence of such early collisional processes. Converging continental plates are not linear and the existence of promontories and embayments greatly influence the timing and nature of collision in different areas. In ad-

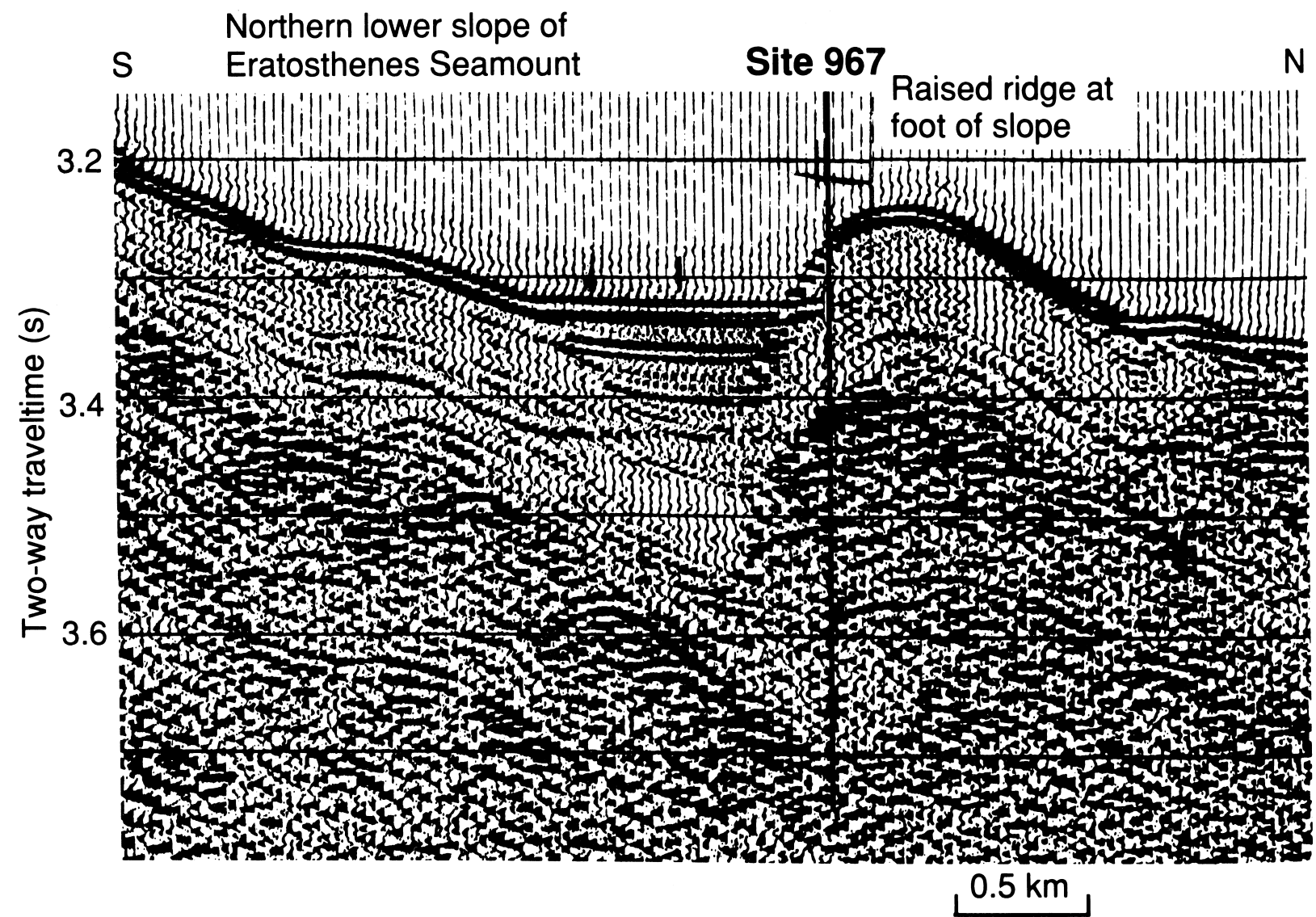

Figure 6. Single-channel seismic profile from the northern margin of the Eratosthenes platform to the base of the southern Cyprus slope. TREDMAR Line 120 (Limonov et al., 1994). The Eratosthenes platform is breaking up and being thrust beneath southern Cyprus, with a sediment-filled trench above. Note the prominent raised ridge at the base of the northern slope of Eratosthenes. The raised feature is interpreted as a thrust culmination above a blind thrust, related to detachment of a sliver of Eratosthenes limestones related to subduction and collision (from Robertson et al., 1995c). 


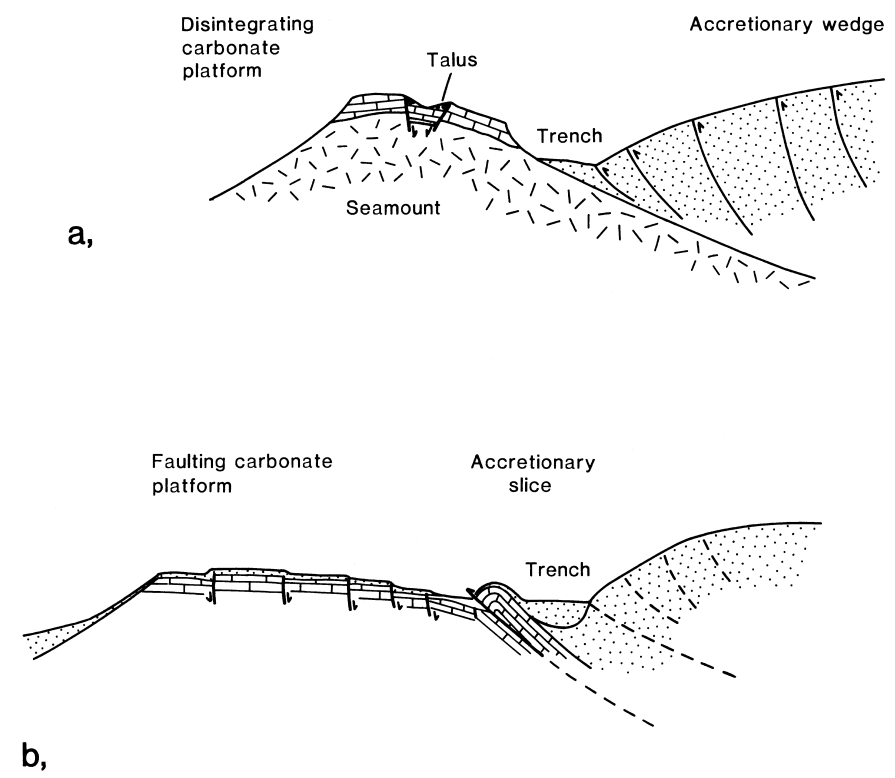

Figure 7. Collision of crustal fragments with a subduction zone. A. Collision of a mainly volcanic seamount with a trench, based on the Daisha Seamount in the Japan trench (Taira et al., 1989). B. Collision of a mainly continental crust fragment with a trench, based on the Eratosthenes Seamount (Limonov et al., 1994; Robertson, 1997). Model showing processes active when an oceanic seamount arrives at a trench. Note the role of normal faulting in both cases.

dition, rifted continental slivers, or oceanic edifices, may be accreted before suturing of larger continental plates. The arrival of an oceanic seamount at a trench has already been shown to involve subsidence and break-up of a volcanic edifice, as in the case of the Daisha Seamount in the Japan trench (Taira et al., 1989; Fig. 7A). Specifically, the seamount undergoes strong extensional faulting as it impinges on the trench. This extensional faulting is comparable to that imaged on the Eratosthenes Seamount plateau area and northern margin using seismic data (Limonov et al., 1994; Robertson et al., 1997; Fig 7B). One difference between Daisha and Eratosthenes, however, is that Daisha, the oceanic seamount, is being consumed within the trench, whereas a slice of the Eratosthenes crust is being detached and accreted along its northern margin. The probable explanation for this difference is the contrast in density (and thus buoyancy) between oceanic crust, and Eratosthenes that is underlain by "transitional-type" crust (i.e., probably thinned continental crust with igneous bodies at depth).

The drilling results from Leg 160 thus help with the general problem of the preservation of continental fragments and carbonate platforms within on-land accretionary units (e.g., Tethys, or the Paleozoic Caledonian-Appalachian belt). In the case of the Daisha Seamount the bulk of the volcanic basement is being consumed within the trench. In future, little trace of its existence will remain, other than volcanic-sedimentary debris flows and detached blocks incorporated into an accretionary prism, whereas the bulk of the seamount would be subducted. This debris would then have a high chance of ultimate preservation in the stratigraphic record and can be regarded as equivalents to widespread "olistostromes" (i.e., sedimentary melange) found in many on-land accretionary terrains, including Japan. Elsewhere, the Mariana and Izu-Bonin trenches in the Western Pacific seamounts $<40 \mathrm{~km}$ in diameter were strongly fragmented before subduction, whereas larger seamounts $(40-100 \mathrm{~km})$ remained less fractured before subduction (Fryer et al., 1985; Fryer and Smoot, 1985).

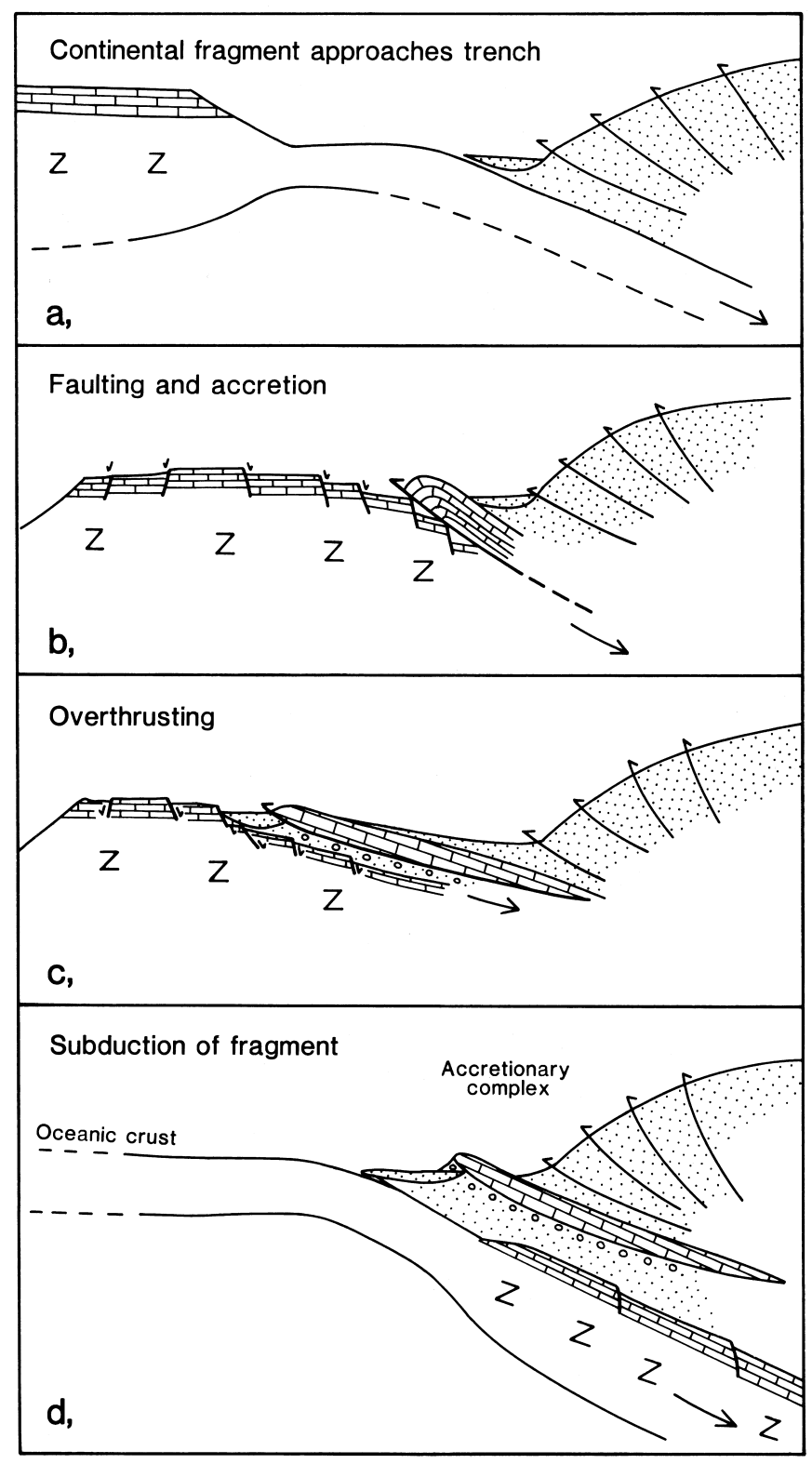

Figure 8. Model for the fate of a continental fragment approaching a subduction zone: (A) steady-state subduction and accretion; (B) fragment collides with trench; part of leading edge is detached and uplifted; (C) bulk of the fragment continues to be subducted; (D) the seamount is subducted leaving only thrust slices of its carapace and possible melange; steady state subduction is resumed. However, if the crustal fragment is too large to be consumed by subduction the trench may be relocated oceanward and may change polarity. See text for discussion.

The breakup of smaller seamounts is attributed to bending of the oceanic plate before subduction. At least one seamount also exhibits fracture zones that parallel the trench axis and displays other deformation features (ridges and trenches) on the adjacent plate.

The ultimate fate of Eratosthenes Seamount could also involve underthrusting and deep-burial beneath an overriding plate (Fig. 8). Whereas the main part of the Eratosthenes Seamount might be subducted; however, at least one crustal sliver $(\sim 1 \mathrm{~km}$ thick) is likely to be accreted and thus have a high preservation potential. Such a pre- 
served slice, such as at Site 967, would comprise a basement of brecciated limestone (tectonic melange?) above a thrust fault, then an approximately $400-\mathrm{m}$-thick slice of pelagic carbonates, overlain by a hemipelagic succession, with sapropels, and then terrigenous turbidites. Similar crustal fragments have been preserved by processes of subduction and accretion and are widely exposed in the Tethyan belt on land and elsewhere (e.g., see Robertson, 1994, for review of literature). Such units include carbonate platform fragments that were accreted, for example, in the latest Permian-early Mesozoic in older (Paleotethyan) units in northern Turkey, and equivalents in western Turkey. Similar units in the Greek area were accreted in the midMesozoic from the Pindos ocean of northern Greece. Accretion of similar units also took place in the Late Cretaceous-early Tertiary in both the Greek and southern Turkish areas (e.g., Antalya Complex).

Such accretion of small thrust slices is, however, not a viable mechanism to emplace large carbonate platforms on the scale of many kilometers across and kilometers thick, as commonly observed in the Tethyan orogen and elsewhere. Examples of such carbonate platforms in the Tethyan orogenic belt include the Parnassus platform in Greece and the Menderes-Bey Dağları carbonate platform in southwest Turkey (see Robertson et al., 1991a, for review). Carbonate platforms on this scale were perhaps too large to be accreted as discrete thrust slices, but were instead preserved by other means. One possibility involves oceanward relocation of a subduction zone of the same polarity. Alternatively, site survey results from the Eratosthenes Seamount suggest that the southern margin of Eratosthenes is possibly being consumed beneath the Levantine Basin to the south (Limonov et al., 1994). Africa-Eurasia convergence could in future be accommodated by both northward and southward underthrusting of the Eratosthenes Seamount. Thus, Eratosthenes may in future not be thrust far beneath Cyprus (and metamorphosed), but may instead remain at a high structural level between collided plates, where it could be exhumed and eroded. Subduction zone reversal is known in modern tectonic settings in the southwest Pacific area (e.g., Weissel, 1982; Taylor and Karner, 1982) and has been inferred to explain re- gional anomalies in the overall direction of plate convergence in the Eastern Mediterranean region (i.e., in western Turkey; Pickett and Robertson, 1997).

\section{Significance for Ophiolite Emplacement}

One popular model for ophiolite emplacement involves the collision of oceanic crust located above a subduction zone with a passive continental margin. A modern example is the collision of the North Australian margin with the Banda arc (Harris, 1991). In the Eastern Mediterranean and Middle Eastern regions, most of the large ophiolites are inferred, mainly based on geochemical evidence, to have formed above intra-oceanic subduction zones (e.g., Jurassic Pindos ophiolite, northern Greece; Upper Cretaceous Troodos and Semail ophiolites, Oman). These ophiolites were emplaced when an ophiolite that was formed by spreading above a subduction zone later collided with a Tethyan passive margin, either the northern margin of Gondwana (i.e. Oman), or a small rifted continental fragment (e.g. Pelagonian zone, northern Greece). The Leg 160 results document a Tethyan ophiolite actually in the process of being emplaced, an unusual situation (Fig. 9). Most of the other Late Cretaceous ophiolites that formed in the southerly Neotethys (Hatay, Baer-Bassit and Oman) were emplaced onto the African-Arabian passive margin, in the latest Cretaceous and were then transgressed, first by clastic sediments, and then by shallow-water carbonates, as seen in the BaerBassit area of northern Syria. However, the Troodos ophiolite retains an unbroken sedimentary cover following the time of oceanic crust genesis though the Late Cretaceous into the Tertiary (see Robertson, Chap. 54, this volume, for literature review). This rules out a classical model in which the ophiolite was emplaced by long-distance thrusting (hundreds of kilometers) onto the Arabian continental margin from far to the north in the Late Cretaceous (Fig. 9A). Instead, the Troodos ophiolite remained within a remnant of the Neotethyan ocean during the Tertiary. It was then strongly uplifted in the Pliocene and Pleistocene, with most of the uplift taking place in the
North Africa

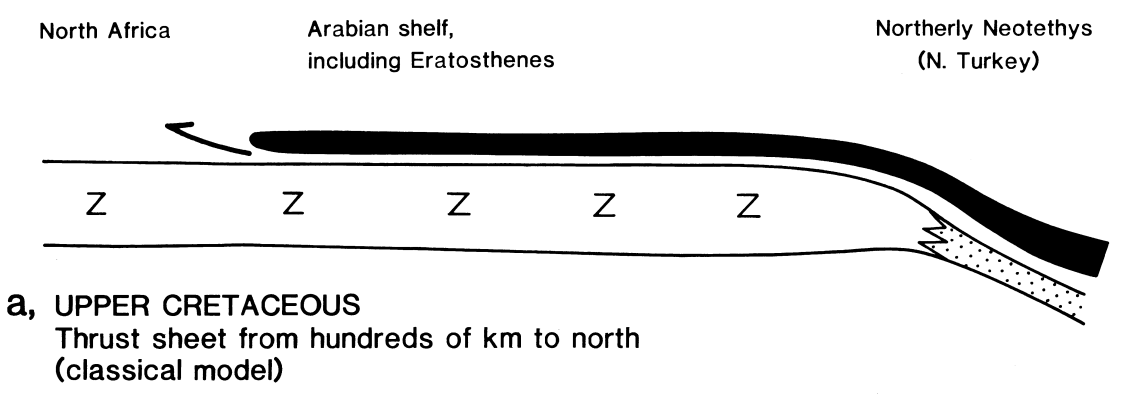

Figure 9. Alternative interpretations of emplacement of the Troodos ophiolite: (A) emplaced as a far-travelled thrust sheet in the Late Cretaceous onto the passive margin of North Africa, followed by marine transgression (Dercourt et al., 1993 and references therein); (B) as a more or less in situ remnant of oceanic lithosphere that remained within Neotethys until collision with the Eratosthenes Seamount in Pliocene-Pleistocene time (Gass and Masson-Smith, 1963; Robertson, 1990).

\section{(classical model)}

Arabian shelf, including Eratosthenes therly Neotethy

(N. Turkey)

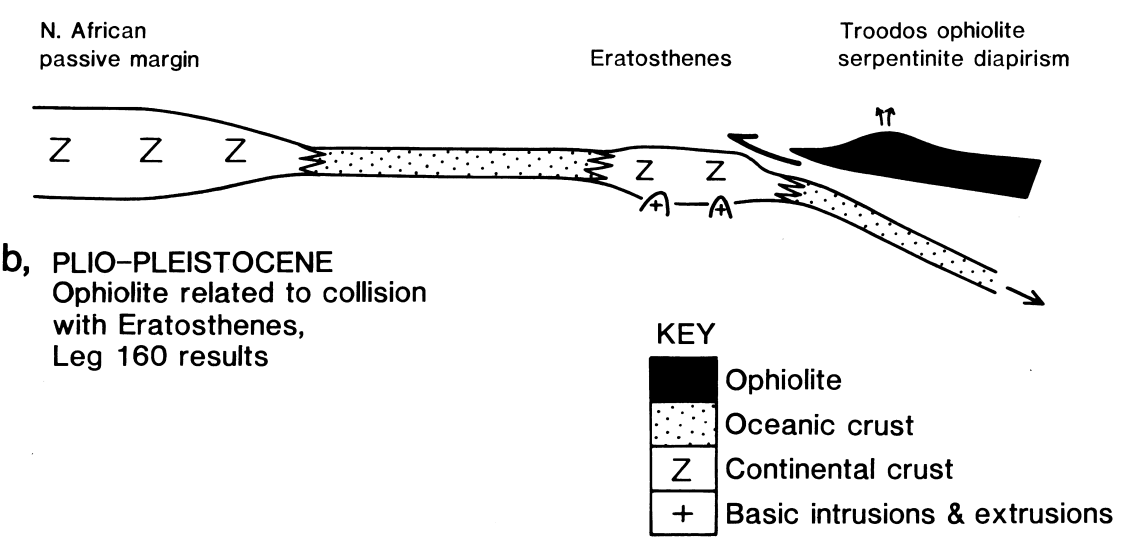


late Pliocene to mid-Pleistocene (see Poole and Robertson, 1992, Chap. 43, this volume, for details; Fig. 9B).

The uplift of the Troodos ophiolite is broadly coeval with collapse of the Eratosthenes Seamount and it is inferred that the two events are causally related. In detail, the first sign of breakup and subsidence of the Eratosthenes carbonate platform is in the early Pliocene. The early Pliocene was a time of relative quiescence in southern Cyprus, as shown by the sedimentary record (Robertson et al., 1991b), and thus does not show the effects of initial collision of the Eratosthenes Seamount. There is excellent evidence of strong, focused uplift of the Troodos ophiolite beginning in the late Pliocene (see Poole and Robertson, Chap. 43, this volume, for literature review). This suggests that an up-to-several-million-year time gap existed between the first signs of disruption of the Eratosthenes Seamount (early Pliocene) and evidence of strong uplift of southern Cyprus (late Pliocene).

A complicating factor in the uplift of the Troodos ophiolite is the effect of serpentinite diapirism, inferred from the occurrence of serpentinite in the core of Mt Olympus (Fig. 1) and gravity data (Gass and Masson-Smith, 1963; Moores and Vine, 1971). The serpentinite protrusion is comparable with diapiric serpentinite that affects other forearc areas, as represented by the Conical Seamount within the Mariana fore-arc (Fryer, 1992). The main difference is that most forearc serpentinite diapirism normally takes place in deeply submerged areas, whereas the Troodos ophiolite was already uplifted to near or above sea level before the Pliocene, when major serpentinite diapir- ism began, followed soon by subaerial exposure. Serpentinite diapirism cannot have been the sole cause of the uplift of southern Cyprus, as a much larger area is also affected including the Kyrenia Range that extends well to the northeast as the Karpas Peninsula (Fig. 1). Underthrusting of the Eratosthenes Seamount beneath southern Cyprus began in the early Pliocene (or slightly earlier?), triggering serpentinite diapirism that did not, however, become very active until the late Pliocene. A combination of the effects of underthrusting and serpentinite diapirism then resulted in updoming and rapid surface uplift of the Troodos ophiolite in the late Pliocene-mid-Pleistocene time. This was associated with rapid erosion of the core of the ophiolite, and dispersal of large volumes of ophiolite-derived sediment, mainly as coarse conglomerates (Poole and Robertson, 1992; Chap. 43 , this volume). In summary, collision of the Eratosthenes Seamount with the Cyprus active margin, combined with serpentinite diapirism, are seen as the main driving force of emplacement of the Troodos ophiolite, with implications for other examples in the geological record.

\section{CONCLUSIONS FROM ERATOSTHENES DRILLING}

The Eratosthenes Seamount south of Cyprus is confirmed to be in the process of incipient collision with a convergent plate boundary, represented by the Cyprus margin to the north (Fig. 10). Based main-
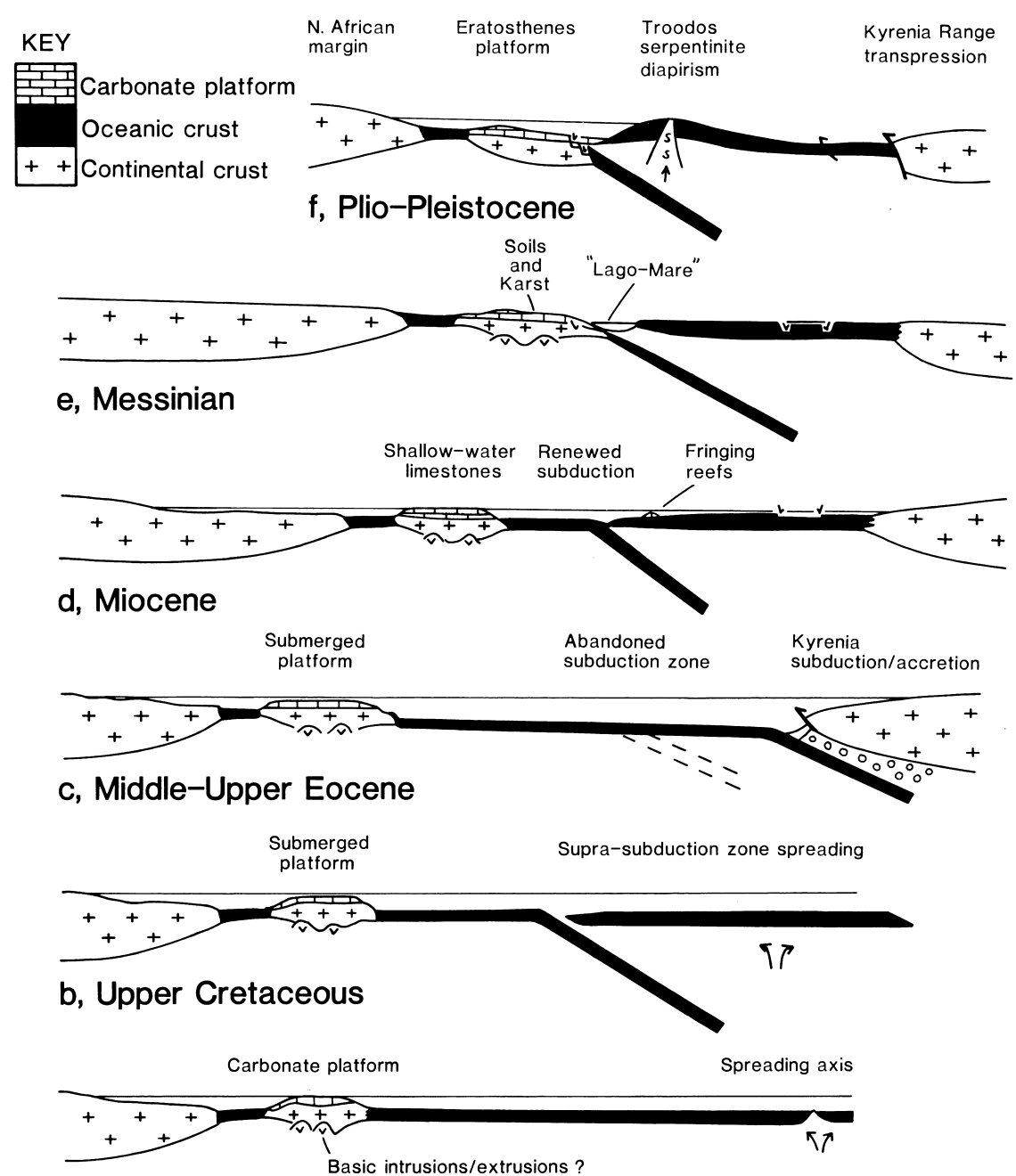

a, Lower Cretaceous ( $\&$ earlier)
Figure 10. Plate tectonic model for the evolution of the Eratosthenes Seamount in relation to Cyprus (see text for explanation). A. Early Cretaceous (and earlier): the Eratosthenes Seamount was probably rifted in the Triassic followed by a long passive margin subsidence history that persisted through the Early Cretaceous, the oldest rocks drilled at Site 967. The spreading axis was then to the north. B. Late Cretaceous: northward intra-oceanic subduction gave rise to the Troodos ophiolite by spreading above a subduction zone. This subduction zone was blocked by collision of the eastward extension of the trench with the promontory of the Arabian passive margin to the east. During early Tertiary time, continued con vergence of Africa and Eurasia was accommodated by subduction in the Turkish area, culminating in collision and southward emplacement of the Kyrenia Range of northern Cyprus. C. Middle-late Eocene: subduction resumed, culminating in emplacement of the Kyrenia Range in the north of Cyprus. D. Miocene (or earlier): the present subduction zone was initiated, and Eratosthenes migrated toward Eurasia. E. The tectonic situation remained unchanged during the Messinian salinity crisis. Eratosthenes approached the Cyprus active margin. F. Eratosthenes began to be thrust beneath the Cyprus active margin (early Pliocene). Serpentinite diapirism was triggered, culminating in rapid surface uplift focused on Mt Olympus during late Pliocene-mid-Pleistocene time. Note: A more realistic tectonic interpretation must take account of the three-dimensional regional tectonic setting, as discussed elsewhere (see Mart and Robertson; Chap. 52, this volume and Robertson, Chap. 54 , this volume. 
ly on existing geophysical information, the Eratosthenes Seamount is inferred to be a continental fragment rifted from the northern margin of the North African plate (i.e., Gondwana) in early Mesozoic time. By Early Cretaceous time (pre-Aptian), the Eratosthenes Seamount took the form of a shallow-water carbonate platform, with the accumulation of neritic carbonates similar to those farther east in the Levant. The Eratosthenes carbonate platform subsided in the Late Cretaceous and was overlain by bathyal pelagic carbonate. It escaped tectonic disruption in the Late Cretaceous at a time when ophiolite genesis and emplacement took place further north, in southern Cyprus and Turkey. Eratosthenes was then still in a relatively southerly position adjacent to the North African passive margin. It was tectonically uplifted by the Miocene time to become a shallow-water carbonate platform. The cause or causes of this uplift remain unclear, but could be related to the effects of regional tectonic upwarp related to initiation of northward subduction of a remnant of Neotethyan oceanic crust within the easternmost Mediterranean area. During the Messinian Mediterranean-wide desiccation crisis, Eratosthenes became emergent, with karst and paleosol development. In the early Pliocene, Eratosthenes was submerged to bathyal depths, accompanied by deposition of localized matrix-supported debris flows, that are seen as being tectonically initiated. The seamount was then transgressed by deep-water hemipelagic muds, including sapropels. Subsidence accelerated in the late Pliocene-Pleistocene. The subsidence is seen as the result of flexural loading, with overthrusting of the Troodos ophiolite along the Cyprus active margin to the north during the initial stages of collision. The tectonic subsidence was accompanied by high-angle extensional faulting that may have exploited preexisting zones of structural weakness within the foreland.

A crustal sliver of the Eratosthenes crust is in the process of thrust detachment near the base of the northern slope of the seamount, based on seismic evidence. Its existence suggests a mechanism for the mode of accretion of comparable carbonate platform slivers within on-land melange terrains (e.g., in Greece and Turkey). The subsidence of the Eratosthenes Seamount and the uplift of Cyprus are intimately related. However, the initial strong relative subsidence of Eratosthenes in the early Pliocene appears to have preceded the main phase of surface uplift of the Troodos ophiolite in the late Pliocenemid-Pleistocene by up to several million years. The uplift was the combined result of collision and diapiric protrusion of serpentinite. These events are intimately related to initial collision of the African and Eurasian plates, with resulting emplacement of the Troodos ophiolite.

\section{ACKNOWLEDGMENTS}

We thank the captain, the crew, and the marine technicians for outstanding support during Leg 160. The manuscript benefited from comments by John Woodside, Ian Alexander, and Kay Emeis. Mrs. Diana Baty assisted with drafting the figures.

\section{REFERENCES}

Almogi-Labin, A., Bein, A., and Sass, E., 1993. Late Cretaceous upwelling along the southern Tethys margin, Israel: interrelationship between productivity, bottom water environments, and organic matter preservation. Paleoceanography, 8:671-690.

Ben-Avraham, Z., Shoham, Y., and Ginzburg, A., 1976. Magnetic anomalies in the eastern Mediterranean and the tectonic setting of the Eratosthenes Seamount. Geophys. J. R. Astron. Soc., 45:105-123.

Ben-Avraham, Z., Tibor, G., Limonov, A.F., Leybov, M.B., Ivanov, M.K.,Tokarev, M.Y., and Woodside, J.M., 1995. Structure and tectonics of the Eastern Cyprus arc. Mar. Pet. Geol., 12:263-271.

Beaumont, C., 1981. Foreland basins. Geophys. J. R. Astron. Soc., 65:291329.
Clube, T., and Robertson, A.H.F., 1986. The palaeorotation of the Troodos microplate, Cyprus, in the Late Mesozoic-early Tertiary plate tectonic framework of the Eastern Mediterranean. Nature, 317:522-525.

Dercourt, J., Ricou, L.F., and Vrielynck, B. (Eds.), 1993. Atlas of Tethys Palaeoenvironmental Maps: Paris (Gauthier-Villars).

Dewey, J.F., and Şengör, A.M.C., 1979. Aegean and surrounding areas: complex multi-plate and continuum tectonics in a convergent zone. Geol. Soc. Am. Bull., 90:84-92.

Eaton, S., 1987. The sedimentology of Mid-Late Miocene carbonates and evaporites in southern Cyprus [Ph.D. thesis]. Univ. of Edinburgh.

Eaton, S., and Robertson, A.H.F., 1993. The Miocene Pakhna Formation, Cyprus, and its relationship to the Neogene tectonic evolution of the Eastern Mediterranean. Sediment. Geol., 86:273-296.

Emeis, K.-C., Robertson, A.H.F., Richter, C., et al., 1996. Proc. ODP, Init. Repts., 160: College Station, TX (Ocean Drilling Program).

Flecker, R., Ellam, R.M., Muller, C., Poisson, A., Robertson, A.H.F., and Turner, J., in press. Application of $\mathrm{Sr}$ isotopic stratigraphy to the origin and evolution of the Neogene Isparta Angle, southern Turkey. Tectonophysics.

Flecker, R., Robertson, A.H.F., Poisson, A., and Muller, C., 1995. Facies and tectonic significance of two contrasting Miocene basins in southern coastal Turkey. In Robertson, A.H.F., and Grasso, M. (Eds.), Thematic Set: Later Tertiary-Quaternary Mediterranean Tectonics and PalaeoEnvironments. Terra Nova, 7:221-233.

Follows, E.J., 1992. Patterns of reef sedimentation and diagenesis in the Miocene of Cyprus. Sediment. Geol., 79:225-253.

Follows, E.J., and Robertson, A.H.F., 1990. Sedimentology and structural setting of Miocene reefal limestones in Cyprus. In Malpas, J., Moores, E.M., Panayiotou, A., and Xenophontos, C. (Eds.), Ophiolites: Oceanic Crustal Analogues: Nicosia, Cyprus (Geol. Surv. Dep., Minist. Agric. Nat. Resour.), 207-216.

Follows, E.J., Robertson, A.H.F., and Scoffin, T.P., 1996. Tectonic controls of Miocene reefs and related carbonate facies in Cyprus. In Fransee, E.K., Esteban, M., Ward, W.C., and Rouchy, J.-M. (Eds.), Models for Carbonate Stratigraphy from Miocene Reef Complexes of Mediterranean Regions. Concepts Sedimentol. Paleontol., 5:295-316.

Fryer, P., 1992. A synthesis of Leg 125 drilling of serpentine seamounts on the Mariana and Izu-Bonin forearcs. In Fryer, P., Pearce, J.A., Stokking, L.B., et al., Proc. ODP, Sci. Results, 125: College Station, TX (Ocean Drilling Program), 95-112.

Fryer, P., Ambos, E.L., and Hussong, D.M., 1985. Origin and emplacement of Mariana forearc seamounts. Geology, 13:774-777.

Fryer, P., and Smoot, N.C., 1985. Processes of seamount subduction in the Mariana and Izu-Bonin trenches. Mar. Geol., 64:77-90.

Gardiner, W., Grasso, M., Sedgeley, D., 1994. Plio-Pleistocene fault movement as evidence for mega-block kinematics within the Hyblean-Malta Plateau, Central Mediterranean. J. Geodynamics, 19:35-51.

Garfunkel, Z., and Derin, B., 1984. Permian-early Mesozoic tectonism and continental margin formation in Israel and its implications for the history of the Eastern Mediterranean. In Dixon, J.E., and Robertson, A.H.F. (Eds.), The Geological Evolution of the Eastern Mediterranean. Geol. Soc. Spec. Publ. London, 17:187-201.

Gass, I.G., MacLeod, C.J., Murton, B.J., Panayiotou, A., Simonian, K.O., and Xenophontos, C., 1994. The Geology of the South Troodos Transform Fault Zone. Mem., Cyprus Geol. Surv. Dep., 9:218.

Gass, I.G., and Masson-Smith, D., 1963. The geology and gravity anomalies of the Troodos Massif, Cyprus. Phil. Trans. R. Soc. London A, 255:417467.

Haimson, B.C., Lee, M.Y., Baumgartner, J., and Rummel, F., 1990. Plate tectonics and structure inferences from in situ stress measurements and fracture logging in drillhole CY 4, Troodos ophiolite, Cyprus. In Malpas, J., Moores, E.M., Panayiotou, A., and Xenophontos, C. (Eds.), Ophiolites and Oceanic Lithosphere. Proc. Internat. Symp. Troodos 1987, Nicosia, Cyprus, Geol. Surv. Dep., 125-130.

Harris, R.A., 1991. Temporal distribution of strain in the active Banda orogen: a reconciliation of rival hypotheses. J. Southeast Asian Earth Sci., 6:373-386.

Hayward, A B., Robertson, A.H.F., and Scoffin, T.P., 1996. Miocene patch reefs from a Mediterranean marginal terrigenous setting in S.W. Turkey. In Fransee, E.K., Esteban, M., Ward, W.C., and Rouchy, J.-M. (Eds.), Models for Carbonate Stratigraphy from Miocene Reef Complexes of Mediterranean Regions. Concepts Sedimentol. Paleontol., 5:317-332. 
Hsü, K.J., Cita, M.B., and Ryan, W.B.F., 1973. The origin of the Mediterranean evaporites. In Ryan, W.B.F., Hsü, K.J., et al., Init. Repts. DSDP, 13 (Pt. 2): Washington (U.S. Govt. Printing Office), 1203-1231.

Hsü, K.J., Montadert, L., et al., 1978. Init. Repts. DSDP, 42 (Pt. 1): Washington (U.S. Govt. Printing Office).

Kempler, D., 1993. Tectonic patterns in the Eastern Mediterranean [Ph.D. thesis]. Hebrew Univ., Jerusalem.

Kopf, A., and Flecker, R., 1996. Problems associated with the interpretation of normal fault distributions in sediments recovered by the advanced hydraulic piston corer during Leg 160, Eastern Mediterranean. In Emeis, K.-C., Robertson, A.H.F., Richter, C., et al., Proc. ODP, Init. Repts., 160: College Station, TX (Ocean Drilling Program), 507-511.

Krasheninnikov, V.A., Udintsev, G.B., Mouraviov, V., and Hall, J.K., 1994. Geological structure of the Eratosthenes Seamount. In Krasheninnikov, V.A., and Hall, J.K. (Eds.), Geological Structure of the Northeastern Mediterranean (Cruise 5 of the Research Vessel Akademik Nokolaj Strakhov): Jerusalem (Historial Productions-Hall Ltd.), 113-130.

Limonov, A.F., Woodside, J.M., and Ivanov, M.K. (Eds.), 1994. Mud Volcanism in the Mediterranean and Black Seas and Shallow Structure of the Eratosthenes Seamount. Initial Results of the Geological and Geophysical Investigations during the Third "Training-through-Research" Cruise of the R/V Gelendzhik (June-July 1993). UNESCO Rep. Mar. Sci., 64.

Livermore, R.A., and Smith, A.G., 1984. Some boundary conditions for the evolution of the Mediterranean region. In Stanley, D.J., and Wezel, F.-C. (Eds.), Geological Evolution of the Mediterranean Basin: Berlin (Springer-Verlag), 83-100.

Mart, Y., 1997. Salt diapirs south of the Eratosthenes Seamount: structural extension in a zone of collision. EUG 9, Eur. Union of Geosci., Strasburg (France), Abstract Suppl. 1, Terra Nova, 9:395.

Mart, Y., Robertson, A.H.F., and Woodside, J., 1997. Cretaceous tectonic setting of Eratosthenes Seamount in the eastern Mediterranean Neotethys: initial results of ODP Leg 160. C.R. Acad. Sci. Ser. 2a, 324:127-134.

McCallum, J.E., Scrutton, R.A., Robertson, A.H.F., and Ferrari, W., 1993. Seismostratigraphy and Neogene-Recent depositional history of the south central continental margin of Cyprus. Mar. Pet. Geol., 10:426-425.

Moores, E.M., and Vine, F.J., 1971. The Troodos Massif, Cyprus and other ophiolites as oceanic crust: evaluation and implications. Philos. Trans. $R$. Soc. London A, 268:443-466.

Morel, S.W., 1960. The Geology and Mineral Resources of the ApsiouAkrotiri Area. Mem., Cyprus Geol. Surv. Dep., 7:52-88.

Morris, A., Creer, K.M., and Robertson, A.H.F., 1990. Palaeomagnetic evidence for clockwise rotations related to dextral shear along the southern Troodos transform fault, Cyprus. Earth Planet. Sci. Lett., 99:250-262.

Orszag-Sperber, F., Rouchy, J.M., and Elion, P., 1989. The sedimentary expression of regional tectonic events during the Miocene-Pliocene transition in the southern Cyprus basins. Geol. Mag., 126:291-299.

Pickett, E.A., and Robertson, A.H.F., 1997. Formation of the Late Palaeozoic-Early Mesozoic Karakaya Complex and related ophiolites in NW Turkey by Palaeotethyan subduction-accretion. J. Geol. Soc. London, 13:99-1009.

Poole, A.J., and Robertson, A.H.F., 1992. Quaternary uplift and sea-level change at an active plate boundary, Cyprus. J. Geol. Soc. London, 148:909-921.

Reilinger, R.E., McClusky, S.C., Oral, M.B., King, R.W., Toksoz, M.N., Barka, A.A., Kinik, I., Lenk, O., and Sanli, I., 1997. Global positioning system measurements of present-day crustal movements in the ArabiaAfrica-Eurasia plate collision zone. J. Geophys. Res., 102:9983-9999.

Robertson, A.H.F., 1987. The transition of a passive margin to an Upper Cretaceous foreland basin related to ophiolite emplacement in the Oman Mountains. Geol. Soc. Am. Bull., 99:633-653.

- 1990. Tectonic evolution of Cyprus. In Malpas, J., Moores, E.M., Panayiotou, A., and Xenophontos, C. (Eds.), Ophiolites: Oceanic Crustal Analogues. Proc. Symp. "Troodos 1987," Nicosia, Cyprus (Geol. Surv. Dep., Minist. Agric. Nat. Resour.), 235-250.

1994. Role of the tectonic facies concept in orogenic analysis and its application to Tethys in the Eastern Mediterranean region. Earth-Sci. Rev., 37:139-213.

Robertson, A.H.F., Clift, P.D., Degnan, P., and Jones, G., 1991a. Palaeogeographic and palaeotectonic evolution of the Eastern Mediterranean Neotethys. Palaeogeogr., Palaeoclimatol., Palaeoecol., 87:289-344.

Robertson, A.H.F., Dixon, J.E., Brown, S., Collins, A., Morris, A., Pickett, E., Sharp, I., and Ustaömer, T., 1996. Alternative tectonic models for the Late Paleozoic-Early Tertiary development of Tethys in the Eastern Mediterranean region. In Morris, A., and Tarling, D.H. (Eds.), Paleomag- netism and Tectonics of the Mediterranean Region. Geol. Soc. Spec. Publ. London, 105:239-263.

Robertson, A.H.F., Eaton, S., Follows, E.J., and McCallum, J.E., 1991b. The role of local tectonics versus global sea-level change in the Neogene evolution of the Cyprus active margin. In Macdonald, D.I.M. (Ed.), Sedimentation, Tectonics and Eustacy Sea-level Changes at Active Margins. Spec. Publ. Int. Assoc. Sedimentol., 12:331-369.

Robertson, A.H.F., Eaton, S.E., Follows, E.J., and Payne, A.S., 1995a. Sedimentology and depositional processes of Miocene evaporites from Cyprus. Terra Nova, 7:233-254.

Robertson, A.H.F., Emeis, K.-C., Richter, C., Blanc-Valleron, M.-M., Bouloubassi, I., Brumsack, H.-J., Cramp, A., De Lange, G.J., Di Stefano, E., Flecker, R., Frankel, E., Howell, M.W., Janecek, T.R., Jurado-Rodríguez, M.J., Kemp, A.E.S., Koizumi, I., Kopf, A., Major, C.O., Mart, Y., Pribnow, D.F.C., Rabaute, A., Roberts, A.P., Rullkötter, J.H., Sakamoto, T., Spezzaferri, S., Staerker, T.S., Stoner, J.S., Whiting, B.M., and Woodside, J.M., 1995b. Evidence of collisional processes associated with ophiolite obduction in the eastern Mediterranean: results from Ocean Drilling Program Leg 160. GSA Today, 5:213-221.

Robertson, A.H.F., Emeis, K.-C. (Co-Chief Scientists), Richter, C. (Staff Scientist), Blanc-Valleron, M.-M., Bouloubassi, I., Brumsack, H.J., Cramp, A., Di Stefano, G.J., Flecker, R., Frankel, E., Howell, M.W., Janecek, T.R., Jurado-Rodríguez, M.J., Kemp, A.E.S., Koizumi, I., Kopf, A., Major, C.O., Mart, Y., Pribnow, D.F.C., Rabaute, A., Roberts, A.P., Rullkötter, J.H., Sakamoto, T., Spezzaferri, S., Staerker, T.S., Stoner, J.S., Whiting, B.M., and Woodside, J.M., 1997. Collision-related break-up of a carbonate platform (Eratosthenes Seamount) and mud volcanism on the Mediterranean Ridge: preliminary synthesis and implications of tectonic results of ODP Leg 160 in the Eastern Mediterranean Sea. In Cramp, A., MacLeod, C.J., Lee, S.V., and Jones, E.J.W. (Eds.), Geological Evolution of Ocean Basins. Geol. Soc. Spec. Publ. London, 131:243-271.

Robertson, A.H.F., Kidd, R.B., Ivanov, M.K., Limonov, A.F., Woodside, J.M., Galindo-Zaldivar, J., and Nieto, L., 1995c. Eratosthenes Seamount, easternmost Mediterranean: evidence of active collapse and underthrusting beneath the Cyprus active margin. Terra Nova, 7:254-264.

Robertson, A.H.F., and Shipboard Scientific Party, 1996. Role of the Eratosthenes Seamount in collisional processes in the Eastern Mediterranean. In Emeis, K.-C., Robertson, A.H.F., Richter, C., et al., Proc. ODP, Init. Repts., 160: College Station, TX (Ocean Drilling Program), 513520.

Robertson, A.H.F., and Xenophontos, C., 1993. Development of concepts concerning the Troodos ophiolite and adjacent units in Cyprus. In Prichard, H.M., Alabaster, T., Harris, N.B. and Neary, C.R. (Eds), Magmatic Processes and Plate Tectonics. Geol. Soc. Spec. Publ. London, 70:85120.

Ross, D.A., and Uchupi, E., 1977. Structure and sedimentary history of southeastern Mediterranean Sea-Nile Cone. AAPG Bull., 61:872-902.

Rouchy, J.M., 1982. La genèse des évaporites messiniennes de Méditerranée. Mem. Mus. Nat. Hist. Nat., 50:1-267.

Ryan, W.B.F., Stanley, D.J., Hersey, J.B., Fahlquist, D.A., and Allan, T.D., 1971. The tectonics and geology of the Mediterranean Sea. In Maxwell, A.E. (Ed.), The Sea (Vol. 4), 387-492.

Savostin, L.A., Sibuet, J.C., Zonenshain, L.P., Le Pichon, X., and Rolet, J., 1986. Kinematic evolution of the Tethys belt, from the Atlantic to the Pamirs since the Triassic. Tectonophysics, 123:1-35.

Sengör, A.M.C., and Yilmaz, Y., 1981. Tethyan plate tectonic evolution of Turkey: a plate tectonic approach. Tectonophysics, 75:181-241.

Steininger, F.F., and Rögl, F., 1984. Paleogeography and palinspastic reconstruction of the Neogene of the Mediterranean and Paratethys. In Dixon, J.E., and Robertson, A.H.F. (Eds.), The Geological Evolution of the Eastern Mediterranean. Geol. Soc. Spec. Publ. London, 17:659-668.

Stenzel, S.R., Knight, I., and James, N.P., 1990. Carbonate platform to foreland basin: revised stratigraphy of the Table Head Group (Middle Ordovician), western Newfoundland. Can. J. Earth Sci., 27:14-26.

Stockmal, G.S., Beaumont, C., and Boutilier, R., 1986. Geodynamic models of convergent margin tectonics: transition from a rifted margin to overthrust belt and consequences for foreland-basin development. $A A P G$ Bull., 70:727-730.

Taira, A., Tokuyama, H., and Soh, W., 1989. Accretion tectonics and evolution of Japan. In Ben-Avraham, Z. (Ed.), The Evolution of Pacific Ocean Margins: Oxford (Oxford Univ. Press), 100-123.

Taylor, B., and Karner, G.D., 1982. The opening of the Woodlark Basin, subduction of the Woodlark spreading system, and the evolution of northern Melanesia since mid-Pliocene time. Tectonophysics, 87:23-277. 
Tibor, G., Ben-Avraham, Z., Steckler, M., and Fligelman, H., 1992. Late Tertiary subsidence history of the southern Levant margin, Eastern Mediterranean Sea, and its implications to the understanding of the Messinian event. J. Geophys. Res., 97:17593-17614.

Weissel, J.K., 1982. The opening of the Woodlark spreading system, subduction of the Woodlark spreading system and the evolution of northern Melanesia since mid-Pliocene time. Tectonophysics, 87:253-277.

Whiting, B.M., and Thomas, W.A., 1994. Three-dimensional controls on subsidence of a foreland basin associated with a thrust-belt recess: Black Warrior basin, Alabama and Mississippi. Geology, 22:727-730.

Woodside, J.M., 1977. Tectonic elements and crust of the eastern Mediterranean Sea. Mar. Geophys. Res., 3:317-354.
1991. Disruption of the African Plate margin in the eastern Mediterranean. In Salem, M.J., Sbeta, A.M., Bakbak, M., and Rida, M. (Eds.), The Geology of Libya: Symp. Geol. Libya 3, 6:2319-2329.

Woodside, J.M., and Bowin, B., 1970. Gravity anomalies and inferred crustal structure in the eastern Mediterranean Sea. Geol. Soc. Am. Bull., 81:1107-1122.

Date of initial receipt: 13 August 1997

Date of acceptance: 17 November 1997

Ms 160SR-063 